\title{
Of religion and redemption: evidence from default on islamic loans
}

\author{
Baele, Lieven ; Farooq, Moazzam ; Ongena, Steven
}

\begin{abstract}
We compare default rates on conventional and Islamic loans using a comprehensive monthly dataset from Pakistan that follows more than 150,000 loans over the period 2006:04 to 2008:12. We find robust evidence that the default rate on Islamic loans is less than half the default rate on conventional loans. Islamic loans are less likely to default during Ramadan and in big cities if the share of votes to religious-political parties increases, suggesting that religion - either through individual piousness or network effects - may play a role in determining loan default.
\end{abstract}

DOI: https://doi.org/10.1016/j.jbankfin.2014.03.005

Posted at the Zurich Open Repository and Archive, University of Zurich

ZORA URL: https://doi.org/10.5167/uzh-99376

Journal Article

Accepted Version

Originally published at:

Baele, Lieven; Farooq, Moazzam; Ongena, Steven (2014). Of religion and redemption: evidence from default on islamic loans. Journal of Banking and Finance, 44:141-159.

DOI: https://doi.org/10.1016/j.jbankfin.2014.03.005 


\title{
Of Religion and Redemption:
}

\section{Evidence from Default on Islamic Loans}

\author{
Lieven Baele * \\ Netspar, CentER - Tilburg University \\ PO Box 90153, NL 5000 LE Tilburg, The Netherlands \\ Telephone: +31 13 4663257, Fax: +31 134662875 \\ E-mail: lieven.baele@uvt.nl \\ Moazzam Farooq \\ Central Bank of Oman
}

P.O. Box 1161, P.C 112, Ruwi, Sultanate of Oman.

Telephone: +968 2477 7580, Fax: +968 24777767

E-mail: moazzam.farooq@cbo.gov.om

Steven Ongena

University of Zurich, SFI and CEPR

Department of Banking and Finance, Plattenstrasse 32, CH-8032 Zürich, Switzerland
Telephone: +41 44634 3954, Fax: +41 446344903
E-mail: steven.ongena@bf.uzh.ch

This Draft: February 2014

\begin{abstract}
* Corresponding author. We thank an anonymous referee, Nafis Alam, Thorsten Beck, Martin Brown, Estelle Cantillon, Elena Carletti, Paola Conconi, Olivier De Jonghe, Hans Degryse, Muhammed-Shahid Ebrahim, Zuzana Fungáčová, Laurent Gheeraert, Alexandra Girod, Iftekhar Hasan, Vasso Ioannidou, Asim Khwaja, Robert Kollmann, Patrick Legros, Alberto Manconi, Ike Mathur (the editor), Atif Mian, Phil Molyneux, Thomas Mosk, Charlotte Ostergaard, María Fabiana Penas, Gérard Roland, Omar Salah, Koen Schoors, İlkay ŞendenizYüncü, Ahmed Ali Siddiqui, Johannes Spinnewijn, Nora Srzentic, Eva Terberger, Maurizio Zanardi, Chen Zhou, Bilal Zia, participants at the Harvard University Conference on "Islam and Muslim Societies: An Analytical Examination", the DIW - Boston College - FCM - Deutsche Bundesbank Conference on "The Role of Finance in Stabilizing the Past, Present, and Future Real Economy", the Bangor University Conference on Financial Sector Performance and Risk, the UCSIA Conference on "Morals and Banking", the CAREFIN Workshop "Banking on Ideas", and seminar participants at the Bank for International Settlements, the Bank of Finland Institute for Economies in Transition, BI - Norwegian School of Management, CREATES at Aarhus University, De Nederlandsche Bank, Durham University, ECARES at the Université Libre de Bruxelles, the European University Institute (Florence), Ghent University, the Luxembourg School of Finance, the Manchester Business School, the Rotman School of Management at the University of Toronto, Tilburg University, and the Universities of Lugano, St. Gallen, and Piraeus for valuable comments. We are utmost grateful to the State Bank of Pakistan for providing the data used in this paper. The results in this paper do not necessarily represent the views of the Central bank of Oman or the State Bank of Pakistan.
\end{abstract}




\title{
Of Religion and Redemption:
}

\section{Evidence from Default on Islamic Loans}

\begin{abstract}
We compare default rates on conventional and Islamic loans using a comprehensive monthly dataset from Pakistan that follows more than 150,000 loans over the period 2006:04 to 2008:12. We find robust evidence that the default rate on Islamic loans is less than half the default rate on conventional loans. Islamic loans are less likely to default during Ramadan and in big cities if the share of votes to religious-political parties increases, suggesting that religion - either through individual piousness or network effects - may play a role in determining loan default.
\end{abstract}

Keywords: Loan Default, Islamic Loans, Religion, Duration Analysis

JEL: A13, G21, G32, G33, Z12 
Islamic banking is one of the fastest growing parts of the financial sector. Doubled in size since 2006 and already accounting for $\$ 900$ billion or more than 1 percent of the global banking market (Financial Times, May 12, 2011), "the global potential of the Islamic banking market is conservatively estimated at $\$ 4,000$ billion, according to Moody's Investor Service" (Financial Times, July 8, 2008). The financial crisis may have spurred its growth and potential market share even further, as observers claim the "principles based on religious law insulate the industry from the worst of the financial crisis" (Washington Post, October 31, 2008; see also the International Monetary Fund report by Hasan and Dridi (2010)). In particular, the asset-based and risk sharing nature of Islamic finance as well as the obligation to only engage in products that limit excessive leverage and disruptive financial innovation may have shielded Islamic banking from the impact of the crisis.

Yet despite the fast growth of Islamic banking and the imperative claims made about the built-in protection against excessive risk-taking by financial institutions, no research (we are aware of) so far has investigated the default rate of individual conventional versus Islamic loans. This lack of evidence should not come as a surprise, because the identification challenges, and corresponding data requirements, faced by such an analysis are steep. Borrowers seeking Islamic financing and banks granting it may differ from their conventional counterparts in many observable and unobservable characteristics. Whether therefore the difference in credit risk in conventional and Islamic financing is mainly due to compliance with the principles of Islamic law (the Shari'ah) per se, or is due to borrower, loan contract and/or bank characteristics that are independent of any Islamic rulings remains an open question we aim to address in this paper.

The data set we employ covers all business loans that were outstanding in Pakistan during the period 2006:4 to 2008:12. The Credit Information Bureau (CIB) database, that we 
use, is maintained by the Consumer Protection Department of the State Bank of Pakistan and is also analyzed in Khwaja and Mian (2005), Mian (2006), Khwaja and Mian (2008), and Zia (2008) for example. The country and sample period provide a unique setting to analyze the credit risk in Islamic loans. ${ }^{1}$

Pakistan may be one of the few countries in the world where both well-developed conventional and Islamic banking sectors have co-existed for a considerable period of time. Though the characteristics of borrowers, loan contracts and banks may differ between conventional and Islamic loans, their co-existence in Pakistan offers a unique opportunity to assess the effect of religion on the loan default rate. The majority of Islamic loans granted in Pakistan are simple and standard equivalents to conventional loans, and therefore comparable to these conventional loans and to similar Islamic loans in other countries. In fact, the pure profit-loss sharing contracts, i.e., Mudaraba and Musharakah, constitute less than 3 percent of all loans in our sample, compared to 43 percent for Murabahah financing (which is most similar to a term loan), 22 percent for Diminishing Musharakah (most similar to mortgage finance or hire purchase), and 24 percent for Ijarah and Ijarah wa'Iqtina (most similar to a leasing contract). We discuss those contracts in more detail below. Another unique feature of our dataset is that quite a few firms and banks repeatedly and concurrently engage in both conventional and Islamic type financing providing unique opportunities for advanced empirical identification.

\footnotetext{
${ }^{1}$ Consistent with the practices of the Credit Information Bureau (CIB) of the State Bank of Pakistan, we henceforth employ the terms "conventional" and "Islamic loan", despite that because they involve no interest payments and almost always consist of multiple underlying contracts, scholars are often hesitant to label many of the Islamic financial products we will study as "loans" (Kuran (2004)) or even as "Islamic" (see the discussion in Pepinsky (2010) and Khan (2010b) for example).
} 
Estimating a variety of empirical models that contain pertinent combinations of borrower, loan contract and bank characteristics, and even when saturating the models with year*month, borrower, bank and borrower*bank fixed effects, we find robust evidence that Islamic loans are less likely to be overdue for 90 (or 180) days on their payments than conventional loans. This estimated wedge in these default rates is not only statistically significant, but also economically relevant. In duration models the hazard rate on Islamic loans is estimated to be less than half the hazard rate on conventional loans.

The specifications saturated with borrower*bank fixed effects rule out the possibility that observed and/or unobserved borrower, bank and/or borrower-bank relationship heterogeneity are potential explanations for the large observed default differential. Differences in loan characteristics can also be ruled out because - as indicated earlier - the contracted cash flows for the bulk of the Islamic loans in Pakistan are exactly the same as those of their equivalent conventional loans. Indeed, even when pairing simple and common Murabahah loans with their most similar conventional counterparts (i.e., term finance and working capital loans) of the same maturity (i.e., shorter than one year) and of the same collateralization status, the large default differential remains present.

Our hypothesis, which we develop in detail in Section I.C., is that the lower default rates on Islamic loans is due to the more acute conflict that pious borrowers have with their individual religious beliefs or those of their fellow believers when defaulting on an Islamic loan (Iannaccone (1998) and Guiso, Sapienza and Zingales (2006)).

While the most fervent religious believers may obtain Islamic loans only, intermediate believers may mix conventional and Islamic borrowing (a widely observed practice which permits our estimations with borrower fixed effects). Though mixed borrowers may default due to nature or their own actions (Bolton and Scharfstein (1996)), the more pious ones among them may choose (and are legally and observably able) to default on their 
conventional rather than on their Islamic loans. Our finding that the hazard rate on Islamic loans of the same borrower taking both conventional and Islamic loans from the same bank is only one fifth the hazard rate on conventional loans confirms the second hypothesis that we develop, i.e., that the same borrower is less likely to default on an Islamic than on a conventional loan.

Suggestive of religious motivation is further our finding that Islamic loans are less likely to default during Ramadan, a period of greater religious orientation, and in big cities if the share of votes to religious-political parties increases. Family and related social networks may be weaker in big cities and the increase in the share of votes to religious-political parties, which in cities are even more distinct from other political parties than in rural areas, strengthens the role of alternative religious-social networks. Prospective borrowers and loan officers may meet at mosques, for example, which may serve as informal credit registries. Khwaja, Mian and Qamar (2011) estimate the value of membership in such large yet diffuse network - in their case a business network - for the access to bank credit and financial viability using 1999 - 2003 data on the composition of the boards of directors of all firms in Pakistan. $^{2}$

The rest of the paper proceeds as follows. Section I explains the basic tenets of Islamic banking. This section also introduces our corresponding theoretical framework on loan default and the resultant testable hypotheses. Section II introduces the data and the methodology. Section III discusses the empirical results. Section IV concludes.

\footnotetext{
${ }^{2}$ The common bond present in credit unions around the world may fulfill a similar role (McKillop and Wilson (2011)). Ostergaard, Schindele and Vale (2013) for example find that savings banks located in Norwegian communities with high social capital have a higher probability of survival and lower loan losses, though they stress the role social capital plays in facilitating collective decision-making at these banks.
} 


\section{Islamic Banking and Loan Default}

\section{A. Islamic Banking}

Islamic Banking refers to a system of banking or banking practices that is consistent, both in objectives and operations, with the Shari'ah. The main principles are either directly based on the Qur'an and the sayings and actions of the prophet Mohammed, or on a growing body of Islamic jurisprudence that is being developed by Islamic scholars. The key distinguishing features of Islamic Banking - the prohibition of interest (riba), excessive leverage, and its focus on risk sharing - may make Islamic banks quite different from conventional banks. Recently published and ongoing has found that Islamic banks may be less efficient, but at the same time also less exposed to credit risk than conventional banks and that many Islamic banks have high-quality assets and are therefore more stable than their conventional counterparts (Abedifar, Molyneux and Tarazi (2013), Beck, Demirgüç-Kunt and Merrouche (2013), Pappas, Izzeldin, Fuertes and Ongena (2013), Van Wijnbergen and Zaheer (2013); see also Table 1).

[Insert Table 1 about here]

\section{B. Islamic Loan Contracts}

Ideal modes of Islamic financing are based on the profit-and-loss sharing (PLS) paradigm. Examples of such arrangements include Musharakah which is a partnership where all partners invest both money and expertise and Mudarabah which is a partnership with some partners investing only money and others only their skills/labor (we provide details on the different types of Islamic financing in (online) Appendix A). The ex-ante fixed rate of return common in conventional loan products is replaced by a return that is uncertain and dependent on the borrowing company's realized profits, which make these two financing 
structures compatible with Shari'ah principles. Notice that both Musharakah and Mudarabah bear very little resemblance with interest-bearing contracts in conventional banking, which would make it problematic to compare their respective default rates. In practice, however, PLS contracts only constitute a small share of the market for Islamic loans products. In fact, in our sample, less than 3 percent of all Islamic loans are based on the PLS principle. ${ }^{3}$ The low share of PLS lending contracts is not specific to Pakistan. Chong and Liu (2009), for instance, find that only 0.5 percent of Islamic loans in Malaysia adopt the PLS paradigm.

Instead, Islamic banks have developed lending structures that, while being Shari'ah compliant, largely mimic the characteristics of conventional lending products. In a Murabahah contract (which is the contract most equivalent to a term loan), the bank first purchases a real asset from a supplier, and consequently sells it in a different contract at a marked-up price to the borrower. Interest rate payments are implicit as the borrower pays the markup price in installments over a period of time or in lump sum at maturity of the contract. This contract is permissible because trade in general is allowed and also the bank is technically exposed to risk between the moment it takes legal possession of the underlying asset (first contract) and the moment it transfers the asset to the borrower (second contract), even if in practice this moment is often very short.

Similarly, Islamic leasing products have been developed. In case of Ijarah, the bank buys an asset for a customer and then leases it to the customer for a certain period at a fixed rental charge. Islamic law allows rent to be charged because the customer enjoys the usufruct of the good while the bank bears the risk of ownership. Ijarah wa'Iqtina is similar to an Ijarah

\footnotetext{
${ }^{3}$ Often quoted reasons include agency problems, lack of well-defined property laws, the restrictive role of shareholders in management, or a disadvantageous tax treatment. Many banks, facing competition from conventional banks, may consider PLS contracts as being too risky.
} 
contract except that it allows for the possibility that the customer becomes owner of the good at the end of the lease contract, either for free (gift) or at a pre-agreed price. Finally, in a diminishing Musharakah contract, a financier and his client participate either in the joint ownership of a property or an equipment. What is different, however, is that the share of the financier is divided into a number of units, which at pre-agreed moments in time will be purchased by the client. Each period, the client's share increases until all units are bought and he fully owns the property or asset. Rent is paid to the financier according to his remaining share in the project.

C. Theoretical Framework Regarding Default on Conventional and Islamic Loans

The previous section showed that the most popular Islamic lending products are functionally identical to conventional loan products. ${ }^{4}$ Does this mean that we should also expect their default rates to be similar? Clearly, Islamic loans are structured differently and are governed by different contracts than conventional loans. Moreover, there can be different motivations to prefer one form of banking over the other. For example borrowers may choose conventional over Islamic banks because of easy accessibility or specific product needs. If proximity of the closest bank branch or suitability of product is the overriding reason to choose one type of loan over the other, we do not necessarily expect that the default rate on either type of loans will systematically differ.

Nevertheless we think that interesting testable hypotheses can be formed regarding the motivation for preferring one form of credit over the other and the expected default rates associated with that choice. The existence of Islamic banking per se is based on religion and

\footnotetext{
${ }^{4}$ Apart from being functionally identical, conventional and Islamic loans are also subject to a similar tax treatment in Pakistan, in contrast to Malaysia for example where Islamic financing enjoys tax advantages.
} 
for borrowers taking an Islamic loan plainly is a real economic decision (i.e., "putting your money where your mouth is"). An Islamic loan is - after all - a financial product with certain characteristics one of which is its accordance with the Shari'ah. The text that prohibits interest payments, i.e., Al Quran and Hadith, also prohibits the misappropriation of other people's properties (i.e., "the eating other people's money in an unlawful way"). Those who choose to stick to one rule (i.e., the avoidance of interest payments) are expected to have a higher propensity to follow the other rule (i.e., do not default) as well. Put differently, borrowers are likely to base their borrowing and default decisions on a rational comparison of the associated costs of the respective loan contracts. They, when choosing a loan, also take into account the expected cost of default which in the case of a default on an Islamic loan will include possibly acute negative feelings of discordance between intimate religious beliefs and loan outcome.

Following this fundamental prior we propose the following simple framework on the basis of which we derive three distinct testable hypotheses (Figure 1 summarizes the main building blocks and the three testable hypotheses; a model in Box 1 illustrates the main intuition).

\section{[Insert Figure 1 about here]}

We start from the premise that if a person is more personally pious or religiously networked she is ceteris paribus more likely to apply for an Islamic loan than for a conventional loan. To obtain an Islamic loan the applicant has to approach either an Islamic bank or an Islamic branch of a mixed bank which uniquely grant this type of loans. For a conventional loan, on the other hand, the (possibly more secular) applicant needs to approach either a conventional bank or a conventional branch of a mixed bank which uniquely grant that type of loans. 
We further posit that an Islamic bank or branch is ceteris paribus more likely to grant a (Islamic) loan to a more personally pious or religiously networked person. ${ }^{5}$ From this we can deduce that the more personally pious or religiously networked are more likely to have Islamic loans granted by an Islamic bank or branch (which by no means exclude the possibility that these borrowers may also have some conventional loans).

Next, we presume that a more personally pious or religiously networked borrower is less likely to default on a loan (i.e., on any loan) than a more secular borrower. We further posit that if a more pious or networked borrower has multiple loans outstanding she is less likely to default on those loans that are deemed to be in closest accordance with her religious tenets. Islamic loans should clearly be considered to be more in accordance with her religious tenets than conventional loans, while Islamic loans from Islamic banks are likely to be considered to be more so than Islamic loans from Islamic branches (as these branches will be part of a mixed bank).

In sum, the outlined direct match between applicants, banks and contracts suggests the following three testable null hypotheses (between parentheses we mention for simplicity a one-sided alternative hypothesis though we will conservatively test its two-sided equivalent):

\footnotetext{
${ }^{5}$ Banks may also be concerned about the differential judicial risk in Islamic lending (Jobst (2007)), as can turn both to Shari'ah courts, which rule on a case-by-case basis and to regular courts which may also turn the Shari'ah when faced with an Islamic loan. To avoid this "double jeopardy" banks may screen Islamic loan applicants more strictly or evergreen non-performing Islamic loans by rolling them into new Islamic loans or even conventional loans. All these actions will likely mitigate (or at least delay) Islamic loan default. On the other hand, conventional loans can also be challenged on the basis of the Shari'ah. Moreover, most (conventional and Islamic) loans in our dataset are highly standardized and hence carry minimal judicial risk, and our definition of loan default (i.e., a 90-day non-performance) far pre-dates any possible judicial activity. For all these reasons we can all but rule out the practical relevancy of differential judicial risk for our estimates.
} 
Hypothesis 1: Across all borrowers, ceteris paribus, Islamic loans are equally (less) likely to default than conventional loans. This is also (especially) the case for those Islamic loans that are granted by an Islamic bank.

Hypothesis 2: For the same borrower, any Islamic loan taken is equally (less) likely to default than any conventional loan that is taken.

Hypothesis 3: For more personally pious or religiously networked borrowers, ceteris paribus, Islamic loans are equally (less) likely to default.

To test these hypotheses our analysis will need to rely on a variety of borrower, loan contract and bank controls and fixed effects to account for both observed and unobserved borrower, loan contract and bank heterogeneity.

\section{Data and Methodology}

\section{A. Data Description}

We analyze loan level data obtained from the Consumer Protection Department (CPD) of the State Bank of Pakistan that maintains the domestic credit registry, i.e., the Credit Information Bureau (CIB). The monthly available data covers all business loans outstanding in Pakistan from 2006:4 to 2008:12, including both the run-up to and the financial crisis itself (for 16 months each if one takes 2007:08 as the start date of the crisis). ${ }^{6}$ All loans were

\footnotetext{
${ }^{6}$ As the financial sector still maintains limited, albeit growing, linkages with global financial markets, Pakistan has been relatively well-insulated against contagion coming from international financial markets (Mansoor Ali (2009)). In fact, discount rates remained rather high for the entire sample period to address significant macroeconomic imbalances in the domestic economy.
} 
granted in the local currency, the Pakistani rupee (code: PKR. 1 USD $\sim 79$ PKR, 1 EUR 110 PKR on December $\left.31^{\text {st }}, 2008\right)$.

All banks in Pakistan are required to consult the CIB to verify the credit history of a loan applicant if the application exceeds PKR 500,000, and this requirement is similar for conventional and Islamic loans. The CIB data set is also, therefore, thought to be of good quality and has already been studied in different contexts by Khwaja and Mian (2005), Mian (2006), Khwaja and Mian (2008), and Zia (2008) for example. ${ }^{7}$

For each loan contract the CIB records the identity code and total exposure of the borrower and his location and industry. While we do not have financial information on the borrowers other than the precise loan characteristics, we do know that each borrower meets a specific threshold of financial soundness and is required to have a debt to equity ratio of $4: 1$ or better, and a current ratio of at least 1. Deviations from these requirements are allowed only in exceptional cases.

The CIB further reports key loan characteristics, such as the exact financial loan product name, default status, maturity, collateralization, whether cash is immediately disbursed or whether the loan is contingent, loan use for export or agricultural purposes, the approved limit and the remaining outstanding amount. The loan rate is also available for a subset of loans. Finally, the CIB records a unique and matching code for the lending bank and the branch where the loan is granted.

\footnotetext{
${ }^{7}$ As in these papers we do not observe loan need and/or demand to account for the "double" selection bias. Neither do we observe loan applications to study the approval of applications and/or loan granting. But we are mainly interested in the differential loan default probabilities and control for observed and unobserved loan contract, borrower, bank, borrower-bank and time heterogeneity with combinations of characteristics and fixed effects.
} 
Our analysis of individual loan performance commences from the point when a unique credit decision is made. We therefore focus on new loans and loans that are renewed, extended or altered during the sample period. If a borrower obtains two different credit lines for example then both are considered as separate loans. During our 32-month sample period there are 1,238,574 loan-months related to distinct new loans out of a total of almost 4 million loan-months involving 107 financial institutions. Table 2 provides the sample details.

[Insert Table 2 about here]

We discard all loans given to the federal, provincial or local governments, financial intermediaries, autonomous bodies and public sector enterprises because these non-corporate borrowers either cannot default on domestic currency loans, or have different default dynamics that are beyond the scope of this paper. We also exclude from our analysis micro loans of less than PKR 50,000 (retaining them does not alter results), loans larger than PKR 419,000,000, infrastructure and other special loans, and loans granted by financial institutions that are not registered as banks.

Our final dataset consists of 603,677 complete loan-month observations, which corresponds to 152,730 loans granted to 22,723 borrowers by 40 different banks. ${ }^{8}$ Around 5 percent of our sample involves Islamic loans $(32,199$ loan-months), that are granted either by one of the six Islamic banks in our sample $(15,153$ loan-months) or by an Islamic branch or subsidiary of one of the twelve "mixed" banks that offer both conventional and Islamic loans (17,046 loan-months). All bank names (and types) are listed in (online) Appendix B. As of December 2008 there were 8,225 conventional and 514 Islamic bank branches.

\footnotetext{
${ }^{8}$ This attrition we face (which is also caused by data availability) from 107 financial institutions to 40 banks is similar to Khwaja and Mian (2008) who study 42 banks out 145 financial institutions.
} 
About 43 percent of the Islamic financing in our sample is Murabahah financing, about 22 percent is Diminishing Musharakah, and about 24 percent is Ijarah and Ijarah wa'Iqtina. The pure profit and loss sharing (partnership) contracts, Mudaraba and Musharakah, constitute a very small fraction of the market, i.e., only 2 percent and 1 percent, respectively.

Crucially for our identification strategy is the observation that within the sample period quite a few borrowers and banks have balance sheets containing both conventional and Islamic loans. As indicated in Table 3 in total 91,008 loan-months involve borrowers that obtain both loan types, while in total 378,649 loan-months involve one of the twelve mixed banks. For 17,381 loan-months the same borrower within the sample period obtains conventional and Islamic loans from the same bank.

[Insert Table 3 about here]

Table 4 reports detailed summary statistics for both conventional and Islamic loans. Crucial for our analysis is the definition of default. We define default to occur if 90 days after the maturity date or the date of an interest payment and/or installment, the debt balance remains unpaid. This definition for default is standard and identical for conventional and Islamic loans. In both cases default is not only self-reported by the banks upon prescription of the supervisor, but also carefully checked by the supervisor (every year around 80 percent of loans are randomly checked by supervisors, also for telltale signs of evergreening which if discovered carries penalties for the bank). Later on, we confirm the robustness of our findings if we define default to occur if loans payments are overdue for 180 days rather than 90 days.

[Insert Table 4 about here]

We observe a substantially lower monthly default rate for Islamic compared to conventional loans. This difference ( 0.5 percent versus 0.9 percent) is not only statistically 
significant but also economically important. The difference in monthly default rate on Islamic loans granted by an Islamic branch or subsidiary of a conventional bank or by an Islamic bank ( 0.7 percent versus 0.2 percent) is not statistically significant. For completeness the table also reports the right-censored loan duration, i.e., the time to repayment, default or end of the sample period.

We measure the size of the borrower as the natural log of the sum of all credit facilities (loan limits) that are granted to a borrower by all banks. Borrowers with Islamic loans are larger and are located more often in big cities than other borrowers.

Conventional and Islamic loans statistically differ in all contract characteristics at the one percent level, though the differences are often economically small. According to the means conventional loans have a shorter maturity (15 versus 18 months), are less likely to be collateralized (93 versus 99 percent) and to involve an immediate cash disbursal (74 versus 82 percent) or a durable / fixed asset (14 versus 27 percent), are more likely to be for export or agricultural purposes (11 versus 4 percent and 4 versus 0 percent), and are smaller (PKR 23 versus 35 million) than Islamic loans. Interest rates, which we observe for 239,943 loanmonths (i.e., 40 percent of our sample), are on average 2 percentage points lower for conventional than for Islamic loans. ${ }^{9}$ The medians point in a similar direction. Both conventional and Islamic loans can have a fixed or a variable "interest rate" (called "mark-up rate" in case of Islamic loans).

Conventional loans are proportionally more often granted by government, specialized, domestic or large banks than Islamic loans. In absolute terms most conventional and Islamic

\footnotetext{
${ }^{9}$ The higher average loan rate on Islamic loans is not inconsistent with its Islamic character, as borrowers may be willing to pay extra for the extra utility they get from the loans being 'Islamic'. The 2 percent yield difference seems (far) too large to be explained only by the somewhat larger contractual/legal uncertainty embedded in Islamic relative to conventional loans.
} 
loans are granted by privately (often internationally) owned and domestically incorporated banks, such as Meezan, Standard Chartered, RBS, Dubai Islamic, Emirates Global for example.

\section{B. Methodology}

This sub-section briefly discusses the econometric methodology employed in analyzing the time until repayment or default of the individual bank loans. The hazard function in duration analysis provides us with a suitable method for summarizing the relationship between the time to default and the likelihood of default. The hazard rate effectively has an intuitive interpretation as the per-period probability of loan default provided the loan "survives" up to that period. Compared to simple binary default models, duration models explain the time to default, while accounting for the variation in loan maturity. We therefore report estimates based on duration models. In particular we rely on so-called parametric Weibull specifications to determine the shape of the hazard function with respect to time, but resort to Cox (1972) proportional hazard models to handle inclusion of many fixed effects. Yet, our analysis commences with two representative logit specifications, whose estimates despite the potentially serious limitations of these models - turn out to be qualitatively similar.

Repayment of a loan or the sample period's end may prevent us from ever observing a default on this loan. Such a loan can be considered right censored. Not knowing when the default would occur, means we are unable to observe the "true" time to default for these loans. With no adjustment to account for censoring, maximum likelihood estimation of the proportional hazard models produces biased and inconsistent estimates of model parameters. Accounting for right-censored observations will be accomplished in duration analysis by expressing the log-likelihood function as a weighted average of the sample density of 
"completed" loans and the survivor function of "uncompleted" loans. As the sample period runs from 2006:04 to 2008:12, but the median loan maturity is only twelve months, about 5 percent of all loans are right-censored because of the sample period's end. As our sample consists out of only new loans granted from 2006:04 onwards, there is no left censoring problem.

\section{Empirical Results}

\section{A. First Specifications}

Table 5 presents maximum likelihood estimation results for different duration models. As a starting point, however, we first report estimates from parsimonious logit specifications (Models I to III). The dependent variable in Model I equals one if the loan defaults and equals zero otherwise and we retain only those 122,331 loans that are either repaid or defaulted within the sample period. The dependent variable in Models II and III equals one if the loan defaults in a certain month, and equals zero otherwise, and in this specification all 152,730 loans (also those that are right-censored) are included given that the estimation in this case is done at the loan-month level (there are 603,677 loan-months).

The estimated intercept terms in Models I and II that equal $-3.228 * * *$ and $-4.752 * * *{ }^{10}$ respectively, imply a probability of default for conventional lending that equals 4.3 percent per loan $\left(=\mathrm{e}^{-3.228} /\left[\mathrm{e}^{-3.228}+1\right]\right)$ and 0.9 percent per loan-month $\left(=\mathrm{e}^{-4.752} /\left[\mathrm{e}^{-4.752}+1\right]\right)$, which equals the mean probability of default per month of conventional loans reported in Table 4. The estimated coefficients on the Islamic Loan dummy that equal $-0.500 * * *$ and $-0.612 * * *$, respectively, suggest that the odds ratio almost halves when a loan is Islamic to 2.6 and 0.5

\footnotetext{
${ }^{10}$ As in the Tables, *,**, and $* * *$ indicate significance at the $10 \%, 5 \%$, and $1 \%$ levels, respectively.
} 
percent, respectively $\left(\mathrm{e}^{-3.228-0.500} /\left[\mathrm{e}^{-3.228-0.500}+1\right]\right.$ and $\left.\mathrm{e}^{-4.752-0.612} /\left[\mathrm{e}^{-4.752-0.612}+1\right]\right)$. Results are unaffected when we add borrower, loan, and bank characteristics to the logit specification in Model III.

[Insert Table 5 about here]

Because we want to account for duration dependence, our main empirical results are established using duration models. Columns IV to VII report results from a duration model that uses the Weibull distribution as a baseline hazard function. ${ }^{11}$ In all parametric models errors are clustered at the borrower level. Model IV features only the Islamic loan dummy (and an intercept) and in Model V we add borrower size as well as 7 borrower region and 67 borrower industry dummies (all regions and industries are listed in (online) Appendix C) and loan characteristics. In Model VI, we additionally control for bank type and time (i.e., year*month) fixed effects. In Model VII, we distinguish between Islamic loans that are granted by Islamic branches/subsidiaries of conventional banks and Islamic loans that are granted by Islamic banks.

The coefficient for the Islamic Loan dummy is negative and highly statistically significant in all specifications. This is the first main result of our paper: The hazard rate is substantially lower for an Islamic than for a conventional loan, allowing us to reject our first null hypothesis (H.1) which states that across all borrowers, ceteris paribus, Islamic loans are equally likely to default than conventional loans.

11 In the next step we employ Cox proportional hazard models where the baseline hazard is left unparameterized (we also estimate accelerated failure time models with a log-logistic distribution; results are similar and not further reported). 
This effect is robust (we will show) to many additional controls, including borrower, bank, and borrower*bank fixed effects and is economically large. Though we return later to economic relevancy in more detail, by way of preview: The coefficient in Model VI for example implies that the hazard rate of an Islamic loan is only $2 / 3^{\text {rd }}\left(=\mathrm{e}^{-0.402}\right)$ of the hazard rate on a conventional loan.

Model VII further shows that especially Islamic loans granted by Islamic banks have a lower hazard rate (allowing us to reject the second part of $H .1$ as well). The hazard rate of Islamic loans issued by Islamic branches or subsidiaries of conventional banks, though lower, is not statistically different from that of all conventional loans. However, our analysis in Table 7 will show that the hazard rate of Islamic loans issued by Islamic branches or subsidiaries of these mixed banks is statistically lower than the hazard rate of the conventional loans issued by these mixed banks. Hence the picture that arises is that Islamic loans issued by Islamic banks have the lowest hazard rate and that conventional loans issued by purely conventional banks have a lower hazard rate than those issued by mixed banks.

Before further model developments, however, we briefly review the estimated coefficients on the control variables. In our sample, we do not find a robust relationship between borrower size and hazard rates. With respect to loan characteristics, we find the hazard rate to be higher for loans with a longer maturity and those involving an immediate cash disbursal (in which case borrowers likely have to start paying back sooner), but lower for collateralized and agricultural loans (though the statistical significance of these findings later disappears somewhat).

Hazard rates are significantly higher for loans issued by government banks and by those belonging to the largest five banks by loan volume, but lower for loans issued by foreign banks. Our finding of higher hazard rates for loans issued by government banks is consistent with results in Khwaja and Mian (2005), who find that loans given to politically 
connected firms by government banks in particular tend to have to up to 50 percent higher default rates. Note that at this point we do not include bank fixed effects (yet) because these effects would be perfectly correlated with the Islamic loan dummy for (loans granted by) the purely conventional or Islamic banks. We include bank fixed effects later on when we focus on the mixed banks (Section III.C, Table 7). Finally, we note that the parameter $\alpha$ is measuring the duration dependence in the baseline hazard specification and that this estimated parameter is not significantly different from one, indicating that there is neither positive nor negative duration dependence.

Borrower, loan and/or bank characteristics that differ between conventional and Islamic loans may be responsible for the estimated difference in the hazard rates. We now systematically investigate each of these possible sources of variation.

\section{B. Differences between Borrowers that Obtain Conventional and Islamic Loans?}

Models V and VI in Table 5 control for borrower size, region, and industry, for example, yet these controls may not capture all borrower heterogeneity. In Model VIII we, therefore, include borrower fixed effects to capture all time-invariant unobservable and observable borrower heterogeneity in a Cox proportional hazard model that leaves the baseline hazard un-parameterized (including this many fixed effects in a Weibull specification is technically impossible in our setting). We designate this specification as our benchmark. Notice that we are able to control for borrower fixed effects because our dataset includes borrowers that have both conventional and Islamic loans (we label such borrowers as "mixed borrowers"), some of which default on one or more loans but not on others (this is possible given our 90 days loan-specific definition of non-performance).

We find that the parameter estimate for the Islamic loan dummy remains negative and statistically significant. Moreover, its magnitude is comparable to the other specifications, 
and even slightly more negative than in the previous most complete specification without borrower fixed effects (in Model VI). Hence these estimates indicate that within the 32month sample period (but controlling for year*month fixed effects) the same borrower is more likely to default on a conventional loan than on an Islamic loan, allowing us also to reject our second null hypothesis $(H .2)$ which states that for the same borrower, any Islamic loan taken is equally likely to default than any conventional loan that is taken. We revisit this finding, and especially its potential relationship with religion, in Section III.E.

[Insert Figure 2 about here]

For our benchmark Model VIII we more closely assess the economic relevancy of our findings for a one-year (median), collateralized, cash loan that is not for export or agricultural purposes, or granted by a government, specialized, foreign or large bank. Figure 2 displays the resulting schedule of the cumulative hazard of conventional and Islamic loans respectively. After one year (the median loan duration), the difference in the cumulative hazard is already more than 2 percent. This first-year cumulative hazard rate on conventional loans equals 5.2 percent, not uncommon for loans in a developing economy, while the firstyear cumulative hazard rate for Islamic loans equals 3.1 percent, more equal to the default rates on loans commonly observed in developed economies.

\section{Differences in the Loan Contracts?}

Despite the controls for the loan maturity, collateralization, cash disbursal, and the export or agricultural purpose of the loan, it is still possible that differences in loan contract characteristics between conventional and Islamic loans would explain the difference in hazard rates. In Table 6 we report a set of specifications that addresses this possibility.

We start by excluding the 45,254 non-cash facilities that may differ more between conventional and Islamic loans in other loan characteristics. We are left with 107,476 loans 
and re-estimate all duration models in Table 5. Model I in Table 6 reports the estimates for the representative benchmark specification. Results are almost unaffected.

[Insert Table 6 about here]

Our data set does not include loan seniority, possibly because seniority of small business loans is often by default based on their precedence in time. In Model II we therefore include a variable Seniority of Charge that equals one if the loan is the only one outstanding, and equals zero otherwise. The coefficient on this new variable is insignificant, while the coefficient on Islamic Loan is unaffected.

One variable we have not included yet in the specifications, as we know it is rather coarsely measured, is the durability or fixity of the asset that is financed with the loan. The bank's ownership claim in a Murabahah contract will be quite limited (in time) if the financed asset is for example an inventory of raw materials that is being used in the production process (recall that almost all Islamic loans are in addition also collateralized). Model III in Table 6 includes the variable Durable that equals one if the loan is granted for a durable or fixed asset, like a plant, machinery, real estate or automobile for example, and equals zero otherwise, in the representative benchmark model. The coefficient on this new variable is also insignificant, while the coefficient on Islamic Loan is again unaffected.

Next, and to account at once for other loan characteristics that are not recorded and for time-varying borrower heterogeneity that is also unobservable to us but that may be observable to the bank, we add the loan rate (Interest Rate) in Model IV or the individual loan amount (Amount) in Model V. As described in the data section, we have the interest rate for only 40 percent of our sample observations. As expected, we find a positive relation between the loan rate or size, and the probability of default. However, the estimate for the Islamic loan dummy remains almost unaltered, i.e., $-0.406^{* *}$ and $-0.506^{* * *}$, respectively. 
Next, we perform additional robustness checks with respect to collateralization and Islamic loan type (to conserve space we chose not to tabulate the estimated coefficients). Banks possibly adjust collateralization depending on borrower condition or additional financing, and may do so differently - if not in principle, then in practice - for the two types of loans. To account for this possibility we simply remove collateral from the base specification. The coefficient on the Islamic loan dummy remains virtually unaffected. To account for the potentially differential nature of collateral in conventional and Islamic lending we add an interaction between the Collateral and Islamic Loan dummies to our benchmark specification. The interaction effect is, however, not statistically significant, and the coefficient on the Islamic Loan dummy remains again unaffected. Similarly we add interactions between all loan contract characteristics and the Islamic loan dummy. With the exception of the negative coefficient on the interaction with maturity, none of the estimated coefficients on the other interactions is statistically significant, and Islamic loans are still found to default less likely than conventional loans.

To account for the different types of Islamic loan contracts, in Model VI we split the Islamic Loan dummy into four loan type dummies, i.e., Murabahah, Diminishing Musharakah, Ijarah or Ijarah wa'Iqtina, and Other Islamic loans (which includes Mudarabah loans for example). The estimated coefficients on the four dummies equal $0.445^{*},-0.886^{*},-0.558^{*}$, and -0.263 , respectively, confirming our findings so far.

We further exclude Musharakah and Mudarabah contracts (both types are more similar to equity financing than to conventional bank credit, and constitute only a tiny fraction of the Islamic loan market). The Islamic Loan coefficient equals $-0.500^{* *}$ (untabulated). In Models VII and VIII we restrict the sample to Murabahah loans and similar conventional loans, i.e., term finance and working capital (excluding all other credit facilities such as mortgage finance, leases, export finance, agricultural finance and off-balance financing for example). In 
Model VIII we further require that the loan maturity is shorter than one year and the loan is collateralized. ${ }^{12}$ In both cases results are unaffected with estimated Islamic Loan coefficients that equal $-0.554 *$ (Model VII) and $-0.587 *$ (Model VIII), respectively. Notice that the last model is very demanding given the very restricted set of loans that is retained (i.e., 44,335 out of 152,730 loans), yet it still manages to include loan maturity, two bank controls, and a full set of time and borrower fixed effects. Hence this specification shows that for the same borrower having both types of loans outstanding, with a maturity shorter than one year and collateralized, the hazard on the Murabahah loans is about half the hazard $\left(=\mathrm{e}^{-0.587}\right)$ than on the very similar conventional loans. On the basis of these specifications we consider it unlikely that loan characteristics by themselves can explain the hazard differential between Islamic and conventional loans.

In Model IX in Table 6 we redefine default to occur only after 180-days. Shorter duration or - when present - tighter covenants for example could result in earlier nonperformance. But results are again unaffected (note that though the number of loans remains equal to 152,730 , the number of loan-months increases to 613,218 , because non-performing loans are now right-censored 90 days later).

Finally, in Model X we study the default on the new loans at bank branches that were opened after 2006:06, i.e., the month with the first six-monthly listing of bank branches within our sample period $(4,061$ new loans that were originated before this first listing were removed). Loans at new branches may have different characteristics, but of course also the

\footnotetext{
${ }^{12}$ Islamic loan contracts may (for technical legal reasons) in some cases result in a swifter loss of access for the borrower to the financed object (a car, for example) than a conventional loan, but in many instances the difference in the timing of the loss of access will be small.
} 
characteristics of the borrowers and loan officers there may differ. Unfortunately because of multicollinearity we have to drop the borrower fixed effects.

At new bank branches the hazard of conventional loans is one third $\left(=\mathrm{e}^{-1.119}\right)$ and the hazard of Islamic loans one tenth $\left(=\mathrm{e}^{-2.384}\right)$ of the hazard of conventional loans at existing branches. Yet, at existing branches the hazard of Islamic loans is now three-quarters $\left(=\mathrm{e}^{-0.259}\right)$ of the hazard of conventional loans at existing branches. So it seems that especially new Islamic branches attract re-paying borrowers. Alternatively, if the new branches would attract worse customers, the loan officers there are aware of the externality of the other banks' screening (Broecker (1990)) and screen themselves more strictly, but then especially so when the branch is Islamic and grants Islamic loans.

In sum, it does not seem to be the case that only differences in loan contract characteristics between conventional and Islamic loans can explain their difference in hazard rates.

D. Differences in the Banks that Grant the Conventional and Islamic Loans?

While we do correct for bank type, our dataset does not include more detailed bank characteristics, such as efficiency, capital ratios, overall riskiness of the loan portfolio, and/or liability structure, for example. Controlling for (time-invariant) bank fixed effects may be important, as default rates may be due to bank-specific clientele effects, risk-taking incentives, and/or screening and monitoring technology.

We therefore include bank fixed effects in a variety of models estimated on the set of loans that are issued only by mixed banks that offer both conventional and Islamic loans. This reduces our sample to 378,649 loan-month observations $(15,653$ borrowers for a total of 109,157 loans). Estimation results are tabulated in Table 7 and the model line-up is similar to Table 5. 
[Insert Table 7 about here]

Models I and II in Table 7 are comparable to Models III and IV in Table 5, except that the estimation results are based on the reduced sample. While the parameter estimates on the controls are mostly similar, we find a substantially stronger Islamic loan effect in the reduced compared to the full sample. This strong effect remains when we introduce first bank fixed effects (and a bank-specific parameter of duration dependence) in Model III, then both borrower and bank fixed effects in Model IV, and finally borrower*bank fixed effects in Model V. In the latter model the hazard rate on Islamic loans is only one fifth of the hazard rate on conventional loans $\left(=\mathrm{e}^{-1.577}\right)$. Hence the same borrower obtaining conventional and Islamic loans from the same bank within the sample period is five times more likely to default on the conventional loan(s) than on the Islamic loan(s).

In Model VI we contrast these mixed borrowers with those having only conventional loans from the mixed banks. The latter type of borrowers are three times more likely to default on their conventional loans than the mixed type of borrowers on their loans $\left(=\mathrm{e}^{1.184}\right)$, while the mixed and Islamic-only borrowers do not differ on average.

In sum, these findings combined suggest that at mixed banks the hazard rates increase as follows: (1) Islamic loans by mixed borrowers, (2) Islamic loans by Islamic-only borrowers, (3) conventional loans by conventional-only borrowers, and (4) conventional loans by mixed borrowers. Or put differently, at mixed banks the difference in hazard rates between conventional and Islamic loans for mixed borrowers is larger than the difference in hazard rates between conventional loans for conventional-only borrowers and the Islamic loans for Islamic-only borrowers. 
Why this wider difference in hazard rates? One possible explanation could reside in the penalties banks charge in case of default. ${ }^{13}$ These penalties flow to the bank in case of nonperformance on a conventional loan yet to a charity (sic) in case of an Islamic loan. In case banks would set penalties optimally (but disregarding other loan terms) they may set the penalties on conventional loans lower than on Islamic loans, especially for borrowers that mix loan types and that are of an intermediate credit quality. ${ }^{14}$

Yet, we do not think differential penalties are the explanation here. First, anecdotal evidence from supervisors with ample field experience in Pakistan suggests that banks may actually set the penalties on conventional and Islamic loans equal to each other. In (online) Appendix D we report the penalties we gleaned from bank websites recently for different household loan types; while not necessarily equal to those specified on the business loans in our study, the penalties the banks list on their website suggest that the penalties on Islamic loans may - if anything - even be lower than those on conventional loans.

Second, when introducing in a variety of specifications the interactions of the Islamic loan dummy with - as a proxy for borrower quality - the observed loan rate and the rate squared, the estimated coefficients on the interaction terms are statistically insignificant but are actually pointing in an opposite direction (i.e., for intermediate loan rate borrowers the

\footnotetext{
${ }^{13}$ Borrowers may also maintain other conventional and Islamic bank products (deposits for example) that are priced jointly with the conventional and Islamic loans respectively by a separate conventional or Islamic bank desk. Any cross-selling across products taken by borrowers or any cross-subsidization across borrowers done at the bank level is absorbed by the borrower*bank fixed effects however. Hence, while interesting per se different funding costs due to different deposit contracting, other variations in product mixes, different bank organization and objectives etc. at these banks cannot be the sole explanation for our findings.

${ }^{14}$ In this way banks would entice non-performance on conventional loans and not only capture the penalties (when paid) on the non-performing conventional loan(s), but also assure continued payment of the higher loan rates on the Islamic loan(s). This penalties strategy may be optimal for borrowers of an intermediate quality, who with a probability between zero and one pay the penalties and repay both loans. For really bad or really good mixed borrowers differentiating penalties between conventional and Islamic loans may be marginally less important. Of course, ex ante banks likely set penalties jointly with the interest (mark-up) rate and other loan terms and/or could provide for example repayment boni.
} 
difference in the hazard rate between conventional and Islamic loan is minimal not maximal as we would expect if penalties are set optimally).

\section{E. Borrower, Bank or Loan Characteristics? Or Religion?}

Until now, we have found consistent evidence that the same borrower is less likely to default on Islamic than on conventional loans obtained from the same bank, and that when borrowing from a mixed bank the difference in hazard rates between conventional and Islamic loans for these mixed borrowers is larger than the difference in hazard rates between conventional loans for conventional-only borrowers and the Islamic loans for Islamic-only borrowers.

One possible explanation for these robust findings is that borrowers may choose not to default on Islamic loans because of their individual religious beliefs. As discussed in the aforementioned Box 1, the motivation to take the Islamic loan may also discourage the borrower from defaulting on it. Alternatively, to the extent that local piousness affects local culture, even relatively less pious borrowers may tend to default less in areas of high religious fervency.

As a first test, in Model VII in Table 7 two variables are introduced that capture whether borrowers (that have both type of loans) during the sample period switch to Islamic or to conventional borrowing, i.e., whether during the sample period conventional loans were obtained first or later than Islamic loans. Those borrowers that switch to Islamic borrowing may be, given the recency of their decision, even more motivated not to default on their Islamic loans.

For this exercise the start of the sample period presents a severe left-censoring problem, i.e., we cannot observe those loans that are no longer outstanding. One additional caveat when interpreting the estimates is that the tighter right-censoring for loans that are recently 
granted may bias the estimated hazard for new loans downward if duration dependence is convex. Hence one has to compare the difference between the two switching coefficients. Though not statistically different, the estimates suggest that individual motivation may play a role. Those borrowers that only recently turned to Islamic loans are even less likely to default on their Islamic loans than those that switched to conventional loans.

While the most fervent religious believers may prefer to obtain Islamic loans only, intermediate fervency may result in mixed borrowing. ${ }^{15}$ Hit by a negative shock large enough to overwhelm their religious resistance to loan default, Islamic-only borrowers have no choice but to default on one of their Islamic loans. On the other hand mixed borrowers do have a choice and despite their lower fervency may on the margin more often decide not to default on their Islamic loans than on their conventional loans. In sum, we think this evidence collected so far is inconsistent with the first part of our third hypothesis (H.3) which states that for more personally pious borrowers, ceteris paribus, Islamic loans are equally likely to default.

However, to establish beyond any doubt that religious beliefs matter for loan default one would need an objective measurement of religiosity for each individual borrower. As far as we are aware no existing research has had access to such a measure, ${ }^{16}$ and neither do we. In

\footnotetext{
${ }^{15}$ We do not think that intermediate piousness and mixed borrowing per se negates religion as a possible determinant of lower Islamic loan default ("some people pray but do not fast"). Of course mixed borrowing may also arise from specific credit needs such as corporate credit cards, export finance supported by the SBP, specific discounting of bills, etc.. Many Islamic scholars would even argue that borrowing at some interest is allowed if the borrower is dealing with hardship and needs to obtain life's necessities such as food and shelter.

${ }^{16}$ Al-Azzam, Hill and Sarangi (2012) find that the repayment delay on 160 group loans in Jordan is negatively affected by the percentage of group members who pray five times a day. More broadly Guiso, Sapienza and Zingales (2013) document that homeowners that find it "morally wrong to walk away" are less likely to say that they are willing to default when the value of their home equity falls below a certain threshold even if they can afford to pay the monthly mortgage costs.
} 
Table 8 we therefore introduce a number of specifications that take further steps in identifying how religion may matter for loan default in this setting.

[Insert Table 8 about here]

Model I in Table 8 introduces a variable Ramadan that equals one if the month is in the Ramadan period and equals zero otherwise. ${ }^{17}$ If either (1) the local network effect of religious activity, and/or (2) the identification of the borrower with Islamic tenets, plays a role in explaining the lower hazard rate on Islamic loans, one would expect this differential between conventional and Islamic loans to widen during the holy Muslim month. ${ }^{18}$ The estimated coefficient on the interaction between Islamic loan and Ramadan is indeed negative and sizeable, i.e., $-0.696^{*}$, implying that during Ramadan months default on Islamic loans drops by more than half $\left(=\mathrm{e}^{-0.696}\right)$.

In case the network effect of religious activity plays a role, the location of the borrower (and/or the bank) may matter. In rural areas (and small towns) there may be more inherent social pressure to repay and more informal help from family and friends in case a borrower faces financial difficulties, and religious affiliation and practice may provide few or no extra network benefits. The distinction between religious and other political parties in rural areas

${ }^{17}$ During the sample period Ramadan took place from September $23^{\text {rd }}, 2006$, to October $22^{\text {nd }}, 2006$, from September $13^{\text {th }}, 2007$, to October $12^{\text {th }} 2007$, and from September $1^{\text {st }}, 2008$, to October $1^{\text {st }}, 2008$. In 2006 and 2007 we consider September and October Ramadan months, in 2008 only September. Given this partial overlap in months we cannot entirely exclude the possibility of a seasonal effect, but it would have to affect conventional and Islamic loans differentially to explain our findings.

${ }^{18}$ Ramadan is a fundamentally shared experience, both within the local community and with other Muslims across the world, and may hence result in both a (temporary) strengthening of local social networks and a surge in the identification with the Muslim world and its practices. Clingingsmith, Khwaja and Kremer (2009) show that identification with the global Muslim community may also strengthen following participation in the Hajj, but we lack individual Hajj participation data to test this conjecture in this context. Following Frieder and Subrahmanyam (2004), Bialkowski, Etebari and Wisniewski (2010) show that equity returns in 14 Muslim markets are substantially higher during Ramadan, while volatility is markedly lower (see also Bialkowski, Bohl, Kaufmann and Wisniewski (2013)). These findings can possibly be attributed to the sentiment of Islamic investors and their trades during this period. 
and small towns may also be less acute than in big cities because rural dwellers may in general be more religious.

We introduce a dummy variable Big City that equals one if borrower is located in a city with more than one million inhabitants and equals zero otherwise. To measure local religious fervency we rely on a variable Share Religious Political Parties, which equals the percentage of total votes obtained for National Assembly seats by the coalition of six religious-political parties in the General Elections of 2002 in the district where the borrower is located. ${ }^{19}$

We interact the Share variable with the Big City dummy. We expect that if the network effects of religion matter the hazard differential between Islamic and conventional loans will increase in the share of religious political parties in big cities (i.e., we expect the estimated coefficient on Islamic Loan * Share * Big City to be negative). ${ }^{20}$

We report the estimates with the Share of Religious Political Parties and Big City variables in Models II and III in Table 8. Notice that the sample now includes only those loans that are granted in the four provinces and the federal capital (i.e., regions where Pakistani political parties can operate) and exclude loans in other regions administered by Pakistan. The results are very interesting. The estimated coefficients in Model III (which includes bank fixed effects) for example suggest that in big cities: (1) the loan hazard rate is on average almost 50 percent higher than in rural areas (i.e., the coefficient on Big City equals $0.486^{* * *}$ ); (2) Islamic loans are relatively more likely to default than in rural areas (i.e., the coefficient on Islamic Loan * Big City equals 0.206, hence is positive and sizeable

\footnotetext{
${ }^{19}$ We use the poll results from the 2002 General Election because 5 of the 6 religious-political parties boycotted the 2008 edition.

20 Borrower size may also be positively correlated with possible religious network effects. In various specifications we indeed find that the coefficient of our measure of borrower size interacted with the Islamic Loan dummy is negative, statistically significant, and economically sizable.
} 
though not significant); and (3) Islamic loans are relatively less likely to default loans if the share of religious parties grows while this is not the case in rural areas (i.e., the coefficient on Islamic Loan * Share * Big City equals $-0.170^{* * *}$, while the coefficient on Islamic Loan * Share equals 0.0429).

This evidence suggests that difference in loan performance of conventional and Islamic loans, especially among urban dwellers that in general may be less pious, may be explained by the network effect of religious activity. Hence, this evidence refutes the second part of our third hypothesis (H.3) which states that for more religiously networked borrowers, ceteris paribus, Islamic loans are equally likely to default.

In robustness we replace the Share of Religious Political Parties with Religious School Enrollment we glean from Andrabi, Das, Khwaja and Zajonc (2006). They define this variable as the number of children enrolled in religious schools as a percentage of total school enrollments in each district (we use the mid-points for the ranges they report). Results (we do not tabulate) again suggest that network effects of religion play a role in determining the differential probability of conventional and Islamic loan repayment, though now the effect is more muted in big cities than in rural areas. Possibly the increased possibilities for pupils to commute in big cities may weaken the correspondence between this measure of local religiosity and the differential in hazard rates.

In a recent study, Pepinsky (2010) argues that the demand for Islamic banking products is determined more by a quest by individuals to claim or maintain a Muslim identify, rather than by religiosity itself. The need for identification tends to be stronger for middle-class borrowers, who are more vulnerable to social dislocation problems induced by modernization and globalization, especially when located in a big city. We hypothesize that in particular these middle-class borrowers that look to strengthen their Muslim identify not only demand 
more Islamic banking products but also have a lower propensity to default on them, especially in big cities.

To test this conjecture, we introduce a variable Share of Post-Natal Private Care which equals the percentage of women that used private (and not public) hospitals or clinics for their post-natal care in the district of the borrower captures the local consumption of a luxury good by the middle class. Models IV and V feature this new Share variable and its interactions. The estimated coefficient on the triple interaction term (almost marginally significant, its p-value equals 0.104 ) suggests that in big cities Islamic loans are less likely to default than conventional loans if the share of post-natal private care grows.

In sum, the reported estimated correlations suggest that in addition to borrower, loan and/or bank loan characteristics, also religion may play some role in determining the differential repayment performance of conventional and Islamic loans, through individual piousness, network effects and maybe also group identification.

\section{Conclusions}

Using a comprehensive monthly dataset from Pakistan that follows more than 150,000 loans over the period 2006:04 to 2008:12, we find compelling evidence that (1) Islamic loans are less likely to default than conventional ones, that (2) the same borrower that has both types of loans is less likely to default on the Islamic loan, and (3) that default propensities are lower for individually pious or religiously networked borrowers. The effects we find are not only statistically significant but also large in economic terms: The hazard rate on Islamic loans is less than half the hazard rate on conventional loans, across many duration models that include a variety of loan contract, borrower, and bank characteristics, where possible combined with time, borrower, bank and/or borrower*bank fixed effects. Similarly, the same borrower obtaining conventional and Islamic loans from the same bank is five times more 
likely to default on the conventional loan(s) than on the Islamic one(s). Consistent with our third hypothesis, we find that defaults are less likely during Ramadan and in big cities where religious parties poll well.

Our paper establishes a link between religiosity and default rates, contributing to a wider literature on the impact of religion on economic outcomes. The co-existence of Islamic and conventional loans (banks) offers a unique opportunity to investigate this link, something that would be much harder to do for other religions where no religion-based financial products exist, at least not on the same scale. Of course, one should be careful in transferring our results towards other religions or value systems, and possibly even to other countries with different regulation and/or banking landscape.

It is important to notice that our study does not aim to address the broader question if conventional or Islamic finance is "better" from either the borrower's, bank's or even society's perspective. Such individual, institutional and public welfare analyses would require for example the collection of detailed data on individual motivations for loan repayment and the aggregation at the bank level of micro-level data, not only on individual bank loans but also on deposits and other bank products, bank organization and processes, among other dimensions.

Our results should also not be interpreted as evidence in favor of a top-down "imposed" Islamic banking system. We belief that the voluntary nature of the current mixed banking system in Pakistan, where candidate borrowers can self-select in either type of borrowing, is key to our understanding of the differential default rates. Imposing Islamic lending across the board would likely change the nature of the game completely (à la "Lucas Critique"). 


\section{References}

Abdul-Majid, M., Saal, D. S. and Battisti, G., 2010. Efficiency in Islamic and Conventional Banking: An International Comparison. Journal of Productivity Analysis 34, 25-43.

Abedifar, P., Molyneux, P. and Tarazi, A., 2013. Risk in Islamic Banking. Review of Finance 17, 2035-2096.

Al-Azzam, M. d., Hill, R. C. and Sarangi, S., 2012. Repayment Performance in Group Lending: Evidence from Jordan. Journal of Development Economics 97, 404-414.

Andrabi, T., Das, J., Khwaja, A. I. and Zajonc, T., 2006. Religious School Enrollment in Pakistan: A Look at the Data. Comparative Education Review 50,

Bader, M. K. I., Mohamad, S., Ariff, M. and Hassan, T., 2008. Cost, Revenue, and Profit Efficiency of Islamic versus Conventional Banks: International Evidence Using Data Envelopment Analysis. Islamic Economic Studies 15, 23-76.

Beck, T., Demirgüç-Kunt, A. and Merrouche, O., 2013. Islamic vs. Conventional Banking: Business Model, Efficiency and Stability. Journal of Banking and Finance 37, 433447.

Bialkowski, J., Etebari, A. and Wisniewski, T. P., 2010. Piety and Profits: Stock Market Anomaly during the Muslim Holy Month. Working Papers in Economics, University of Canterbury.

Bialkowski, J. P., Bohl, M. T., Kaufmann, P. and Wisniewski, T. P., 2013. Do Mutual Fund Managers Exploit the Ramadan Anomaly? Evidence from Turkey. Emerging Markets Review 15, 211-232.

Bolton, P. and Scharfstein, D. S., 1996. Optimal Debt Structure and the Number of Creditors. Journal of Political Economy 104, 1-25.

Broecker, T., 1990. Credit-worthiness Tests and Interbank Competition. Econometrica 58, 429-452.

Chong, B. S. and Liu, M.-H., 2009. Islamic banking: Interest-Free or Interest-Based? PacificBasin Finance Journal 17, 125-144.

Čihák, M. and Hesse, H., 2010. Islamic Banks and Financial Stability: An Empirical Analysis. Journal of Financial Services Research 38, 95-113.

Clingingsmith, D., Khwaja, A. I. and Kremer, M., 2009. Estimating the Impact of The Hajj: Religion and Tolerance in Islam's Global Gathering. Quarterly Journal of Economics 124, 1133-1170.

Cox, D. R., 1972. Regression Models and Life Tables. Journal of the Royal Statistical Society $24,187-201$.

Frieder, L. and Subrahmanyam, A., 2004. Nonsecular Regularities in Returns and Volume. Financial Analysts Journal 60, 29-34.

Ghannouci, W., Fiordelisi, F., Molyneux, P. and Radić, N., 2012. Do Islamic and Conventional Banks Have The Same Technology? Working Paper, Centre for EMEA Banking, Finance and Economics at the London Metropolitan Business School.

Guiso, L., Sapienza, P. and Zingales, L., 2006. Does Culture Affect Economic Outcomes? Journal of Economic Perspectives 20, 23-48.

Guiso, L., Sapienza, P. and Zingales, L., 2013. The Determinants of Attitudes towards Strategic Default on Mortgages. Journal of Finance 68, 1473-1515.

Hasan, M. and Dridi, J., 2010. The Effects of the Global Crisis on Islamic and Conventional Banks: A Comparative Study. Working Paper, International Monetary Fund.

Iannaccone, L. R., 1998. Introduction to the Economics of Religion. Journal of Economic Literature 36, 1465-1495. 
Imam, P. and Kpodar, K., 2010. Islamic Banking: How Has it Diffused? Working Paper, International Monetary Fund.

Jobst, A. A., 2007. The Economics of Islamic Finance and Securitization. Working Paper, International Monetary Fund.

Kettell, B., 2010. Islamic Finance in a Nutshell: A Guide for Non-Specialists. Wiley: West Sussex.

Khan, A. K., 2010a. God, Government and Outsiders: The Influence of Religious Beliefs on Depositor Behavior in an Emerging Market. Mimeo, Harvard.

Khan, A. K. and Khanna, T., 2012. Is Faith a Luxury for the Rich? Examining the Influence of Religious Beliefs on Individual Financial Choices. In: S. Nazim Ali (Eds.), Building Bridges Across Financial Communities: the Global Financial Crisis, Social Responsibility, and Faith-Based Finance. Harvard Law School: Cambridge MA.

Khan, F., 2010b. How 'Islamic' Is Islamic Banking? Journal of Economic Behavior \& Organization 76, 805-820.

Khwaja, A. I. and Mian, A., 2005. Do Lenders Favor Politically Connected Firms? Rent Provision in an Emerging Financial Market. Quarterly Journal of Economics 120, 1371-1411.

Khwaja, A. I. and Mian, A., 2008. Tracing the Impact of Bank Liquidity Shocks: Evidence from an Emerging Market. American Economic Review 98, 1413-1442.

Khwaja, A. I., Mian, A. and Qamar, A., 2011. Bank Credit and Business Networks. Mimeo, Kennedy School of Government, Harvard University.

Kuran, T., 2004. Islam and Mammon: The Economic Predicaments of Islamism. Princeton University Press: Princeton NJ.

Mansoor Ali, M., 2009. Global Financial Crisis: Impact on Pakistan and Policy Response. Speech at Regional High-Level Workshop on "Strengthening the Response to the Global Financial Crisis in Asia-Pacific: The Role of Monetary, Fiscal and External Debt Policies", UN ESCAP.

McKillop, D. and Wilson, J. O. S., 2011. Credit Unions: A Theoretical and Empirical Overview. Financial Markets, Institutions and Instruments 20, 79-123.

Mian, A., 2006. Distance Constraints: The Limits of Foreign Lending in Poor Economies. Journal of Finance 61, 1005-1056.

Mohamad, S., Hassan, T. and Bader, M. K. I., 2008. Efficiency of Conventional versus Islamic Banks: International Evidence using the Stochastic Frontier Approach (SFA). Journal of Islamic Economics, Banking and Finance 4, 107-130.

Ongena, S. and Şendeniz-Yüncü, İ., 2011. Which Firms Engage Small, Foreign, or State Banks? And Who Goes Islamic? Evidence from Turkey. Journal of Banking and Finance 35, 3213-3224.

Ostergaard, C., Schindele, I. and Vale, B., 2013. Social Capital and the Viability of Stakeholder-Oriented Firms: Evidence from Savings Banks. Mimeo, Norwegian School of Management.

Pappas, V., Izzeldin, M., Fuertes, A.-M. and Ongena, S., 2013. A Survival Analysis of Islamic Bank Failure Risk. Mimeo, Lancaster University.

Pepinsky, T. B., 2010. The Demand for Islamic Banking: Piety, Class, and Global Identity. Department of Government, Cornell University.

Van Wijnbergen, S. J. G. and Zaheer, S., 2013. Capital Structure, Risk Shifting and Stability: Conventional and Islamic banking. In: Sajjad Zaheer (Eds.), Financial Intermediation and Monetary Transmission through Conventional and Islamic Channels. Rozenberg Publishing Services: Amsterdam. 
Weill, L., 2011. Do Islamic Banks Have Greater Market Power? Comparative Economic Studies 53, 291-306.

Weill, L. and Godlewski, C. J., 2012. Why Do Large Firms Go for Islamic Loans? Discussion Paper, BOFIT.

Zaheer, S., Ongena, S. and van Wijnbergen, S. J. G., 2013. The Transmission of Monetary Policy Through Conventional and Islamic Banks. International Journal of Central Banking 8, 175-224.

Zia, B. H., 2008. Export Incentives, Financial Constraints, and the (Mis)allocation of Credit: Micro-level Evidence from Subsidized Export Loans. Journal of Financial Economics 498-527. 


\section{Box 1: Religiosity and Loan Default}

Based on (the notation in) Figure 1 the default probabilities of the granted Islamic and conventional loans, i.e., $p_{i}$ and $p_{c}$, equal respectively:

$$
\begin{gathered}
p_{i}=\frac{r x a k+(1-r) y c m}{r x a+(1-r) y c} \\
p_{c}=\frac{r(1-x) b l+(1-r)(1-y) d n}{r(1-x) b+(1-r)(1-y) d}
\end{gathered}
$$

We now make a number of straightforward assumptions based on the fundamental nature of Islamic banking that were outlined in the main text (for simplicity we denote Islamic banks and Islamic branches of mixed banks as Islamic financiers for now but differentiate again later).

Assumption 1: A Muslim applicant is more likely to apply for a loan from an Islamic financier than a secular applicant is (notice that it is possible also for secular applicants to apply for an obtain Islamic loans, i.e., $y \geq 0$ ).

$$
x=\alpha y, \text { with } \frac{1}{y} \geq \alpha>1
$$

Assumption 2: An Islamic financier is more likely to accept an application (which is de iure is always for an Islamic loan) from a Muslim applicant than from a secular applicant.

$$
a=\beta c, \text { with } \frac{1}{c} \geq \beta>1
$$

Assumption 3: An Islamic financier is more (less) likely to accept an application (which de iure is always for an Islamic loan) from a Muslim (secular) applicant than a conventional financier is.

$$
\begin{aligned}
& a=\gamma b, \text { with } \frac{1}{b} \geq \gamma>1 \\
& d=\delta c, \text { with } \frac{1}{c} \geq \delta>1
\end{aligned}
$$

Assumption 4: Given a similar loan, a Muslim borrower is less likely to default on a loan than a secular borrower:

$$
\begin{gathered}
m=\theta k, \text { with } \frac{1}{k} \geq \theta>1 \\
n=\theta l, \text { with } \frac{1}{l} \geq \theta>1
\end{gathered}
$$

Assumption 5: A Muslim borrower is less likely to default on an Islamic loan than on a conventional loan:

$$
\begin{gathered}
l=\mu k, \text { with } \frac{1}{k} \geq \mu>1 \\
\text { So that } n=\delta \mu k
\end{gathered}
$$

Given these assumptions, the default probabilities of the granted Islamic and conventional loans equal:

$$
\begin{gathered}
p_{i}=k \frac{r\left(\alpha-\frac{1}{\beta} \theta\right)+\frac{1}{\beta} \theta}{r\left(\alpha-\frac{1}{\beta}\right)+\frac{1}{\beta}} \\
p_{c}=k \mu \frac{r\left[(1-\alpha y) \frac{1}{\gamma}-(1-y) \delta \frac{1}{\beta} \theta\right]+(1-y) \delta \frac{1}{\beta} \theta}{r\left[(1-\alpha y) \frac{1}{\gamma}-(1-y) \delta \frac{1}{\beta}\right]+(1-y) \delta \frac{1}{\beta}}
\end{gathered}
$$

When all borrowers are secular $(r=0)$ the probabilities equal $p_{i}=k \theta$ and $p_{c}=k \mu \theta$, and $p_{c}>p_{i}$ and $p_{c}-p_{i}=$ $k \theta(\mu-1)>0$. When all borrowers are Muslim $(r=1)$ the probabilities equal $p_{i}=k$ and $p_{c}=k \mu$, and again $p_{c}>p_{i}$ and $p_{c}-p_{i}=k(\mu-1)>0$.

Given how increases in $r$ proportionally decreases the differential default probabilities by a factor $\theta$, and given that analytically it can be shown that $\frac{\delta p_{i}}{\delta r}<0$ and $\frac{\delta^{2} p_{i}}{\delta r^{2}}>0$, and after extensive simulations for many parameter values of both default probability schedules, we conclude that for all $r: p_{c}>p_{i}$.

Hypothesis 1. Across all borrowers, ceteris paribus, Islamic loans are less likely to default than conventional loans.

Notice that Islamic loans granted by Islamic branches of mixed banks could be considered more similar to conventional loans granted by conventional banks. When such loans would be considered perfect substitutes, i.e., when:

$$
\alpha=\beta=v=\delta=\mu=1 \text {. }
$$


Hypothesis 1.1. If Islamic loans from Islamic banks are considered to be more in accordance with religious tenets than Islamic loans from Islamic branches then loans from Islamic banks are even less likely to default than Islamic loans from Islamic branches.

Notice that one alternative reading of the model tree is that we are dealing with the same borrower who is in-between being a Muslim and a secular person. In the case of multiple granted loans such a person would have been applying for (and then servicing) the loan with a probability $r$ as a Muslim and with a probability $1-r$ as a secular person. In that case multiple loans in the portfolio of this borrower may have a different type and will have a difference in default probability according to their type and in what mode the person is acting. But as before, as Islamic financiers are more likely to accept the loan application if the borrower acts as a Muslim, the default rates on the granted Islamic loans will be lower on average than the default rates on the conventional loans.

Hypothesis 2. For the same borrower, an Islamic loan taken is less likely to default than a conventional loan taken.

While it is possible that there are Islamic loans in a person's portfolio that would be taken when this person was acting as a secular person, that possibility decreases in likelihood as a person acts more and more as a Muslim. Therefore if a person is personally very pious or religiously networked $(r \rightarrow 1)$ then it is simple to show that a majority of the Islamic loans taken by this person will be while acting as a Muslim and that their default probability will be commensurately lower.

Hypothesis 3. For more personally pious or religiously networked borrowers, ceteris paribus, Islamic loans are less likely to default. 
The figure displays the extensive form of the loan application, decision and outcome process for Muslim and secular borrowers. A precise explanation of each node and the demarcation of the three stage is provided below the tree. The probability a branch is taken is indicated in italics. $0 \leq r, x, y, a, b, c, d, k, l, m, n \leq 1$. The area in light gray is unobservable to us. For simplicity we denote Islamic banks and Islamic branches of mixed banks as Islamic financiers.
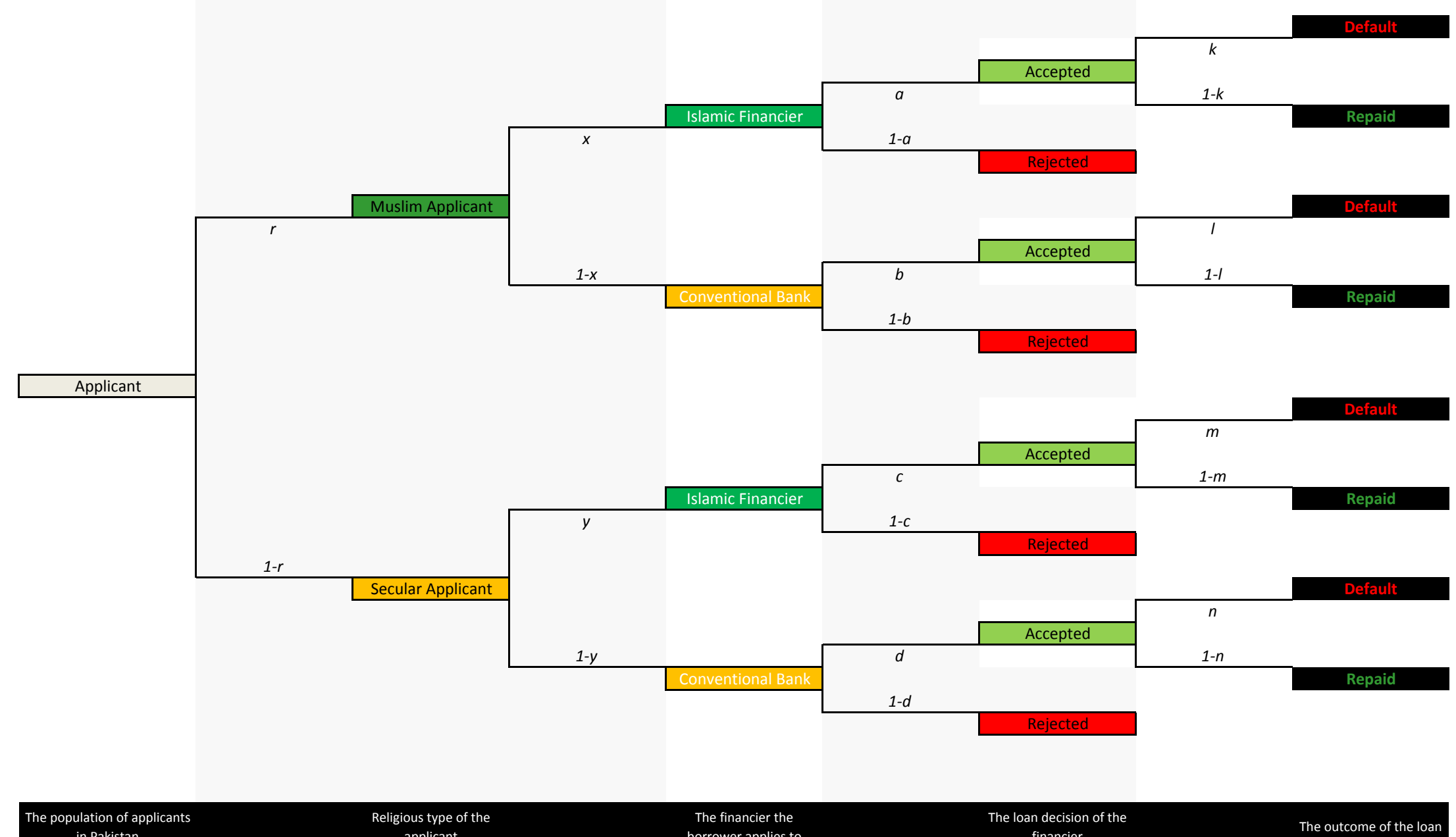

Religious type of the applicant

Stage 0: A proportion of the population is Muslim or secular

Stage 1: Borrower applies to a bank for a loan 


\section{Figure 2.}

The figure displays the cumulative hazard based on the estimated coefficients of Model VIII in Table 5 for a one-year (median) conventional or Islamic loan with all other covariates set at their mean. The cumulative hazard after 12 months (i.e., the vertical line at $t=12$ ) for a conventional loan equals 5.2 percent, for an Islamic loan it equals 3.1 percent.

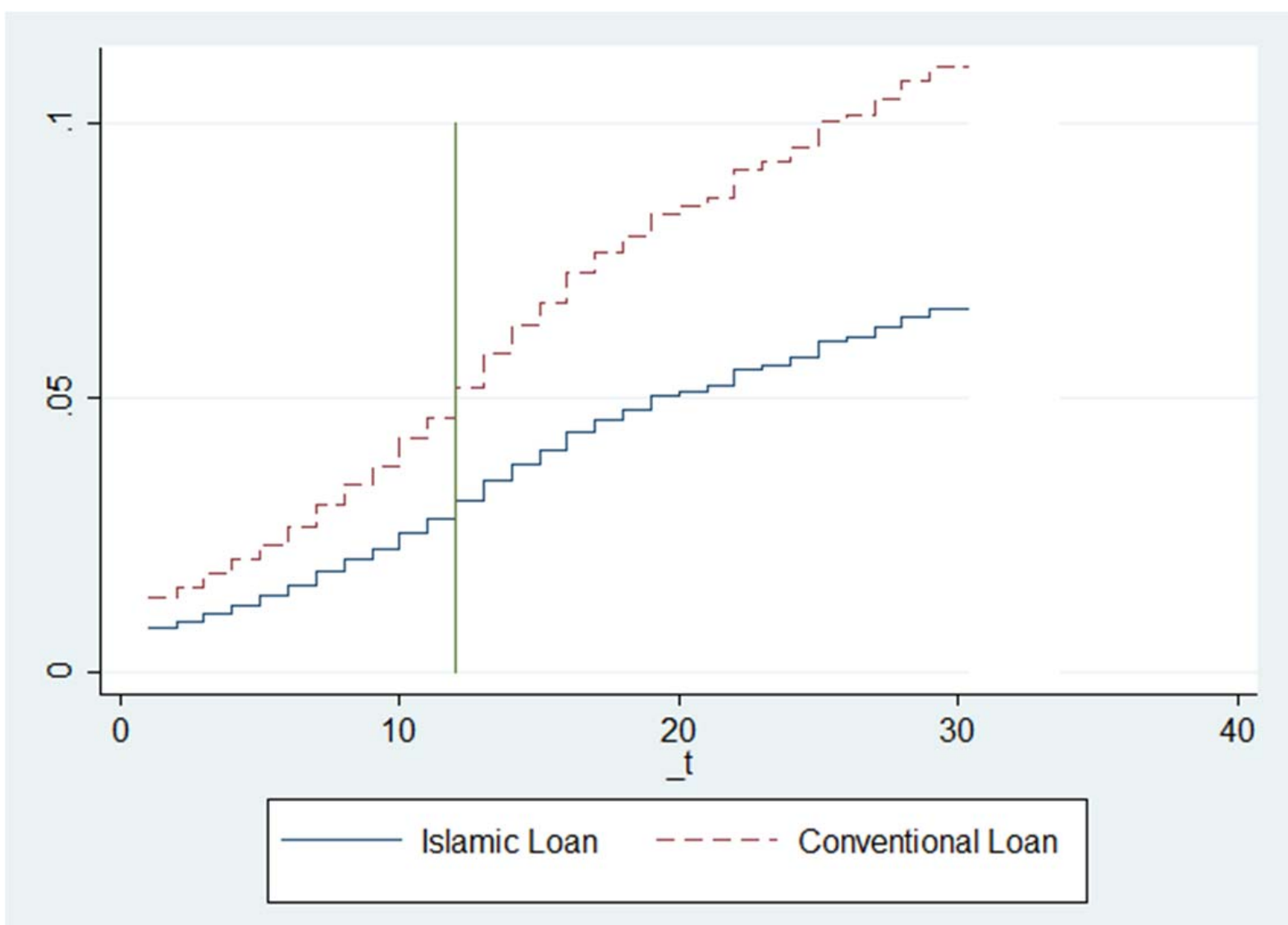




\section{Table 1.}

The table summarizes selected empirical work on Islamic banking.

\begin{tabular}{|c|c|c|c|c|c|c|}
\hline \multirow[t]{2}{*}{ Paper } & \multicolumn{3}{|c|}{ Sample } & \multicolumn{3}{|c|}{ Analysis } \\
\hline & Countries & Period & \# Obs. & At Level & Explains & $\begin{array}{l}\text { Finds (w.r.t. differences between } \\
\text { conventional and Islamic banks / loans) }\end{array}$ \\
\hline Imam and Kpodar (2010) & 117 & $1992-2006$ & 1,520 & Country - Year & Presence & Identifies various factors of diffusion \\
\hline $\begin{array}{l}\text { Mohamad, Hassan and Bader } \\
\text { (2008), Bader, Mohamad, Ariff } \\
\text { and Hassan (2008) }\end{array}$ & 21 & $1990-2005$ & 80 & Bank & Efficiency & No differences \\
\hline Chong and Liu (2009) & Malaysia & 1995:04-2004:04 & 109 & Month & $\begin{array}{l}\text { Average interest } \\
\text { rates }\end{array}$ & $\begin{array}{l}\text { Islamic deposits are not interest-free, but } \\
\text { are closely pegged to conventional } \\
\text { deposits }\end{array}$ \\
\hline Čihák and Hesse (2010) & 18 & $1993-2004$ & 2,347 & Bank - Year & $\begin{array}{l}\text { Z-score } \\
\text { Bank strength }\end{array}$ & $\begin{array}{l}\text { Small Islamic }>\text { small commercial } \\
\text { Large commercial }>\text { large Islamic } \\
\text { Small Islamic }>\text { large Islamic } \\
\end{array}$ \\
\hline $\begin{array}{l}\text { Abdul-Majid, Saal and Battisti } \\
(2010)\end{array}$ & 10 & $1996-2002$ & & Bank - Year & $\begin{array}{l}\text { Technical } \\
\text { inefficiency }\end{array}$ & $\begin{array}{l}\text { Islamic banks are more technically } \\
\text { inefficient }\end{array}$ \\
\hline Pepinsky (2010) & Indonesia & $2008: 05 / 06$ & 2,548 & Consumers & $\begin{array}{l}\text { Views on Islamic } \\
\text { Finance }\end{array}$ & Islamic identity matters, not piety \\
\hline Weill (2011) & 17 & $2000-2007$ & 1,301 & Bank - Year & $\begin{array}{l}\text { Bank market } \\
\text { power (Lerner) }\end{array}$ & $\begin{array}{l}\text { Islamic banks have somewhat less market } \\
\text { power }\end{array}$ \\
\hline $\begin{array}{l}\text { Ongena and Şendeniz-Yüncü } \\
\text { (2011) }\end{array}$ & Turkey & 2008 & 16,056 & Bank - Firm & Firm bank choice & $\begin{array}{l}\text { Islamic banks deal with young, multiple- } \\
\text { bank, industry-focused and transparent } \\
\text { firms }\end{array}$ \\
\hline $\begin{array}{ll}\text { Ghannouci, } & \text { Fiordelisi, } \\
\text { Molyneux and Radić (2012) }\end{array}$ & & $2000-2006$ & 1,505 banks & Bank - Year & Technology & $\begin{array}{l}\text { No technology differences (same cost } \\
\text { efficiency) }\end{array}$ \\
\hline Weill and Godlewski (2012) & 6 & $2001-2009$ & 231 loans & Loans & Islamic & $\begin{array}{l}\text { Choice for Islamic versus conventional } \\
\text { syndicated loans by large firms driven by } \\
\text { country-level religiosity and institutional } \\
\text { quality, not firm-level quality }\end{array}$ \\
\hline $\begin{array}{l}\text { Abedifar, Molyneux and Tarazi } \\
\text { (2013) }\end{array}$ & 24 & 1999-2009 & 553 banks & Bank - Year & $\begin{array}{l}\text { Loan risk, bank } \\
\text { stability }\end{array}$ & $\begin{array}{l}\text { Small Islamic banks that are leveraged or } \\
\text { based in countries with predominantly } \\
\text { Muslim populations have lower credit } \\
\text { risk than conventional banks. Small } \\
\text { Islamic banks also appear more stable }\end{array}$ \\
\hline
\end{tabular}




\begin{tabular}{|c|c|c|c|c|c|}
\hline $\begin{array}{l}\text { Beck, Demirgüç-Kunt and } 22 \\
\text { Merrouche (2013) }\end{array}$ & $1995-2009$ & 510 banks & Bank - Year & $\begin{array}{l}\text { Various bank } \\
\text { measures }\end{array}$ & $\begin{array}{l}\text { Islamic banks are less cost-effective, but } \\
\text { have a higher intermediation ratio, higher } \\
\text { asset quality and are better capitalized, } \\
\text { also during the crisis }\end{array}$ \\
\hline $\begin{array}{l}\text { Pappas, Izzeldin, Fuertes and } 20 \\
\text { Ongena (2013) }\end{array}$ & $1995-2010$ & 421 banks & Bank - Year & Survival & Islamic banks survive longer \\
\hline Khan and Khanna (2012) & 2008 & 9,078 & $\begin{array}{l}\text { Customers at two } \\
\text { banks }\end{array}$ & $\begin{array}{l}\text { Opening bank } \\
\text { account }\end{array}$ & $\begin{array}{l}\text { Religiosity and wealth matters when } \\
\text { opening an Islamic bank account }\end{array}$ \\
\hline Khan (2010a) & 2006:06-2009:03 & 995 & Bank - Account & $\begin{array}{l}\text { Growth deposit } \\
\text { accounts }\end{array}$ & $\begin{array}{l}\text { Islamic deposit accounts grow faster than } \\
\text { conventional ones }\end{array}$ \\
\hline $\begin{array}{l}\text { Van Wijnbergen and Zaheer Pakistan } \\
\text { (2013) }\end{array}$ & 2002:02-2010:08 & 1,696 & $\begin{array}{l}\text { Bank (Branch) - } \\
\text { Quarter }\end{array}$ & $\begin{array}{l}\text { Asset quality, } \\
\text { stability }\end{array}$ & $\begin{array}{l}\text { Islamic bank }>\text { conventional bank } \\
\text { Islamic branch }>\text { conventional branch of } \\
\text { the same bank (except when small) }\end{array}$ \\
\hline $\begin{array}{l}\text { Zaheer, Ongena } \text { and van } \text { Pakistan } \\
\text { Wijnbergen (2013) }\end{array}$ & 2002:II-2010:I & 756 & Bank - Quarter & Credit growth & $\begin{array}{l}\text { Credit channel of monetary policy } \\
\text { through the Islamic banking sector is less } \\
\text { potent than through the conventional part }\end{array}$ \\
\hline This paper & 2006:04-2008:12 & 603,677 & Loan - Month & Loan default & Islamic loans less likely to default \\
\hline
\end{tabular}




\section{Table 2: Sample Composition}

The table reports the composition of the sample. The sample period runs from 2006:04 to 2008:12. Loans to non-corporates include loans to financial intermediaries, public sector enterprises, local, provincial or federal governments, and other autonomous bodies. Micro, special and non-bank loans comprise loans smaller than PKR 50,000, loans larger than PKR 419,000,000, infrastructure and other special loans, and loans granted by financial institutions that are not registered as banks.

\begin{tabular}{l|r|l}
\hline Variable & Number of Observations & Unit \\
\hline All new loans granted & $1,238,574$ & loan - months \\
\multicolumn{1}{l|}{ Minus loans to non-corporates } & 363,221 & loan - months \\
\multicolumn{1}{l|}{ Minus micro, special and non-bank loans } & 252,047 & loan - months \\
\hline Sample loans observed each month & 603,677 & loan - months \\
& 571,478 & loan - months \\
Loans & 32,199 & loan - months \\
Borrowers & 152,730 & loans \\
Banks & 22,723 & borrowers \\
PKR = Pakistanic & 40 & banks \\
\hline
\end{tabular}

PKR = Pakistani Rupee. 1 USD 79 PKR , 1 EUR 110 PKR (December 31, 2008). 
Table 3: Samples for borrowers and banks by loan types

The table reports the number of loan - months for the samples of borrowers and banks by loan type.

Loans observed each month

Granted by banks that offer loans that are

\begin{tabular}{c|l} 
Obtained by borrowers with & $\begin{array}{l}\text { only conventional } \\
\text { loans that are }\end{array}$ \\
Islamic \\
only Islamic
\end{tabular}

Totals

\begin{tabular}{|rcr|}
\hline \multicolumn{3}{|c}{ Granted by banks that offer loans that are } \\
\hline only conventional & $\begin{array}{c}\text { conventional and } \\
\text { Islamic }\end{array}$ & only Islamic \\
\hline 172,120 & 331,675 & - \\
37,755 & 44,946 & 8,307 \\
- & 2,028 & 6,846 \\
\hline
\end{tabular}

Totals

503,795

91,008

8,874

209,875

378,649

15,153

603,677 


\section{Table 4: Summary Statistics on Conventional and Islamic Loans}

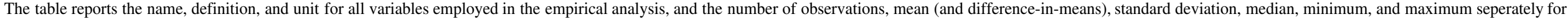

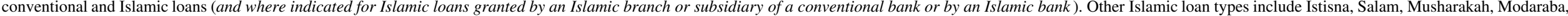
and Qard-e-Hasna loans. The sample period runs from 2006:04 to 2008:12. See the Appendix for the Regions, Industries and Bank types.

\begin{tabular}{|c|c|c|c|c|c|c|c|c|}
\hline Variable & Definition & Unit & Number & Mean & St. Dev. & Median & Minimum & Maximum \\
\hline Islamic Loan & $=1$ if loan is an Islamic loan, $=0$ otherwise & $0 / 1$ & 32,199 & 0.053 & 0.225 & 0 & 0 & 1 \\
\hline by Islamic Branch/Subsidiary & $\begin{array}{l}=1 \text { if the Islamic loan is granted by an Islamic branch or } \\
\text { subsidiary of a conventional bank, }=0 \text { otherwise }\end{array}$ & $0 / 1$ & 17,046 & 0.028 & 0.166 & 0 & 0 & 1 \\
\hline by Islamic Bank & $\begin{array}{l}=1 \text { if the Islamic loan is granted by an Islamic bank, }=0 \\
\text { otherwise }\end{array}$ & $0 / 1$ & 15,153 & 0.025 & 0.156 & 0 & 0 & 1 \\
\hline Murabahah & $=1$ if Islamic loan is a Murabahah loan, $=0$ otherwise & $0 / 1$ & 13,869 & 0.023 & 0.150 & 0 & 0 & 1 \\
\hline Diminishing Musharakah & $\begin{array}{l}=1 \text { if Islamic loan is a Diminishing Musharakah loan, }=0 \\
\text { otherwise }\end{array}$ & $0 / 1$ & 7,219 & 0.012 & 0.109 & 0 & 0 & 1 \\
\hline Ijarah or Ijarah wa' Iqtina & $\begin{array}{l}=1 \text { if Islamic loan is a Ijarah or Ijarah wa' Iqtina loan, }=0 \\
\text { otherwise }\end{array}$ & $0 / 1$ & 7,794 & 0.013 & 0.113 & 0 & 0 & 1 \\
\hline Other & $=1$ if Islamic loan is an other Islamic loan type, $=0$ otherwise & $0 / 1$ & 3,317 & 0.005 & 0.074 & 0 & 0 & 1 \\
\hline
\end{tabular}




\begin{tabular}{|c|c|c|c|c|c|c|c|c|c|c|c|c|c|c|}
\hline \multirow[t]{2}{*}{ Variable } & \multirow[t]{2}{*}{ Definition } & \multirow[t]{2}{*}{ Unit } & \multicolumn{2}{|c|}{ Number } & \multicolumn{2}{|c|}{ Mean } & \multicolumn{2}{|c|}{ St. Dev. } & \multicolumn{2}{|c|}{ Median } & \multicolumn{2}{|c|}{ Minimum } & \multicolumn{2}{|c|}{ Maximum } \\
\hline & & & \begin{tabular}{|l} 
Convent. \\
Loan \\
(Bank)
\end{tabular} & $\begin{array}{c}\text { Islamic } \\
\text { Loan } \\
(\text { Bank }) \\
\end{array}$ & \begin{tabular}{|l} 
Convent. \\
Loan \\
$($ Bank $)$ \\
\end{tabular} & $\begin{array}{cc}\text { Islamic } & \text { Diff. } \\
\text { Loan } & \\
(\text { Bank }) & \\
\end{array}$ & $\begin{array}{c}\text { Convent. } \\
\text { Loan } \\
(\text { Bank }) \\
\end{array}$ & $\begin{array}{l}\text { Islamic } \\
\text { Loan } \\
(\text { Bank }) \\
\end{array}$ & $\begin{array}{c}\text { Convent. } \\
\text { Loan } \\
(\text { Bank }) \\
\end{array}$ & $\begin{array}{c}\text { Islamic } \\
\text { Loan } \\
(\text { Bank })\end{array}$ & $\begin{array}{l}\text { Convent. } \\
\text { Loan } \\
\text { (Bank) } \\
\end{array}$ & $\begin{array}{l}\text { Islamic } \\
\text { Loan } \\
(\text { Bank }) \\
\end{array}$ & $\begin{array}{l}\text { Convent. } \\
\text { Loan } \\
(\text { Bank }) \\
\end{array}$ & $\begin{array}{l}\text { Islamic } \\
\text { Loan } \\
(\text { Bank }) \\
\end{array}$ \\
\hline Loan Performance & & & & & & & & & & & & & & \\
\hline Loan Default & \begin{tabular}{|}
$=1$ if the loan defaults in a certain month, $=0$ otherwise \\
if the Islamic loan is granted by an Islamic branch or subsidiary of a \\
conventional bank (Convent) or by an Islamic bank (Islamic)
\end{tabular} & $\begin{array}{l}0 / 1 \\
0 / 1\end{array}$ & $\begin{array}{r}571,478 \\
17,046\end{array}$ & $\begin{array}{l}32,199 \\
15,153\end{array}$ & $\begin{array}{l}0.009 \\
0.007\end{array}$ & $\begin{array}{l}0.005^{* * *} \\
0.002\end{array}$ & $\begin{array}{l}0.092 \\
0.083\end{array}$ & $\begin{array}{l}0.068 \\
0.045\end{array}$ & $\begin{array}{l}0 \\
0\end{array}$ & $\begin{array}{l}0 \\
0\end{array}$ & $\begin{array}{l}0 \\
0\end{array}$ & $\begin{array}{l}0 \\
0\end{array}$ & $\begin{array}{l}1 \\
1\end{array}$ & $\begin{array}{l}1 \\
1\end{array}$ \\
\hline Duration & \begin{tabular}{|} 
time to repayment, default or end of sample period \\
if the Islamic loan is granted by an Islamic branch or subsidiary of a \\
conventional bank (Convent.) or by an Islamic bank (Islamic)
\end{tabular} & $\begin{array}{l}\text { months } \\
\text { months }\end{array}$ & $\begin{array}{r}571,478 \\
17,046\end{array}$ & $\begin{array}{r}32,199 \\
15,153\end{array}$ & $\begin{array}{l}4.958 \\
4.626\end{array}$ & $\begin{array}{l}4.906 * * \\
5.221\end{array}$ & $\begin{array}{l}4.541 \\
4.159\end{array}$ & $\begin{array}{l}4.473 \\
4.783\end{array}$ & $\begin{array}{l}3 \\
3\end{array}$ & $\begin{array}{l}3 \\
4\end{array}$ & $\begin{array}{l}1 \\
1\end{array}$ & $\begin{array}{l}1 \\
1\end{array}$ & $\begin{array}{l}33 \\
30\end{array}$ & $\begin{array}{l}32 \\
32\end{array}$ \\
\hline Borrower Characteristics & & & & & & & & & & & & & & \\
\hline $\begin{array}{l}\ln (\text { Size }) \\
\text { Region } \\
\text { Industry }\end{array}$ & $\begin{array}{l}\text { the sum of all loans granted by all financial institutions to a } \\
\text { borrower } \\
\text { the natural log of borrower size } \\
\text { location in province or other distinct region } \\
\text { affiliation to industry }\end{array}$ & $\begin{array}{c}\text { mln. PKR } \\
- \\
1 \text { of } 8 \\
1 \text { of } 68\end{array}$ & $\begin{array}{l}571,478 \\
571,478 \\
560,822 \\
556,848\end{array}$ & $\begin{array}{l}32,199 \\
32,199 \\
30,232 \\
29,893\end{array}$ & $\begin{array}{r}329.000 \\
16.849\end{array}$ & $\begin{array}{l}433.000 \\
17.618 * * *\end{array}$ & $\begin{array}{r}1,220.000 \\
2.475\end{array}$ & $1,160.000$ & 16.816 & 17.523 & 10.820 & 10.820 & $\begin{array}{l}80,900 \\
25.109\end{array}$ & $\begin{array}{l}19,100 \\
23.659\end{array}$ \\
\hline Loan Characteristics & & & & & & & & & & & & & & \\
\hline Maturity & period for which loan is granted & months & 571,478 & 32,199 & 15 & $18 * * *$ & 14 & 20 & 12 & 12 & 1 & 1 & 180 & 236 \\
\hline Collateral & $=1$ if loan is collateralized, $=0$ otherwise & $0 / 1$ & 571,478 & 32,199 & 0.929 & $0.991 * * *$ & 0.257 & 0.096 & 1 & 1 & 0 & 0 & 1 & 1 \\
\hline Cash & $=1$ if loan involves immediate cash disbursal, $=0$ otherwise & $0 / 1$ & 571,478 & 32,199 & 0.739 & $0.817 * * *$ & 0.439 & 0.387 & 1 & 1 & 0 & 0 & 1 & 1 \\
\hline Export & $=1$ if loan is used for export, $=0$ otherwise & $0 / 1$ & 571,478 & 32,199 & 0.106 & $0.038 * * *$ & 0.308 & 0.192 & 0 & 0 & 0 & 0 & 1 & 1 \\
\hline Agricultural & $=1$ if loan is used for agricultural activities, $=0$ otherwise & $0 / 1$ & 571,478 & 32,199 & 0.037 & $0 * * *$ & 0.189 & 0 & 0 & 0 & 0 & 0 & 1 & 0 \\
\hline Seniority of Charge & $=1$ if loan taken is the only one outstanding, $=0$ otherwise & $0 / 1$ & 571,478 & 32,199 & 0.379 & $0.360^{* * *}$ & 0.485 & 0.480 & 0 & 0 & 0 & 0 & 1 & 1 \\
\hline Durable & $=1$ if loan is granted for durable/fixed asset, $=0$ otherwise & $0 / 1$ & 571,478 & 32,199 & 0.142 & $0.266 * * *$ & 0.349 & 0.442 & 0 & 0 & 0 & 0 & 1 & 1 \\
\hline Interest Rate & the interest rate on the loan & $\%$ & 234,398 & 5,545 & 12.695 & $14.795 * * *$ & 4.214 & 2.301 & 13.50 & 14.63 & 1.000 & 1.000 & 42.80 & 42.05 \\
\hline Amount & the amount of cash disbursed or the granted limit & 000 PKR & 571,478 & 32,199 & 22,900 & $34,900 * * *$ & 50,400 & 58,000 & 4,800 & 11,400 & 50 & 50 & 419,000 & 418,000 \\
\hline New Bank Branch & $=1$ if loan is granted by a bank branch opened after 2006:06, $=0 \mathrm{o}$ & $0 / 1$ & 571,478 & 32,199 & 0.021 & $0.131 * * *$ & 0.142 & 0.337 & 0 & 0 & 0 & 0 & 1 & 1 \\
\hline Bank Characteristics & & & & & & & & & & & & & & \\
\hline Government & $=1$ if bank is government-owned, $=0$ otherwise & $0 / 1$ & 571,478 & 32,199 & 0.133 & $0.087 * * *$ & 0.340 & 0.282 & 0 & 0 & 0 & 0 & 1 & 1 \\
\hline Specialized & $=1$ if bank is a specialized bank, $=0$ otherwise & $0 / 1$ & 571,478 & 32,199 & 0.038 & 0.000 & 0.191 & 0.000 & 0 & 0 & 0 & 0 & 1 & 0 \\
\hline Foreign & $=1$ if bank is foreign-owned, $=0$ otherwise & $0 / 1$ & 571,478 & 32,199 & 0.018 & $0.174 * * *$ & 0.132 & 0.379 & 0 & 0 & 0 & 0 & 1 & 1 \\
\hline Large & $=1$ if bank is 1 of the 5 largest by loan volume, $=0$ otherwise & $0 / 1$ & 571,478 & 32,199 & 0.367 & $0.055 * * *$ & 0.482 & 0.227 & 0 & 0 & 0 & 0 & 1 & 1 \\
\hline $\begin{array}{l}\text { Time Period Characteristic } \\
\text { Ramadan }\end{array}$ & $=1$ if Ramadan takes place during the month, $=0$ otherwise & $0 / 1$ & 571,478 & 32,199 & 0.132 & 0.131 & 0.339 & 0.337 & 0 & 0 & 0 & 0 & 1 & 1 \\
\hline $\begin{array}{l}\text { Borrower District Characteristics } \\
\text { Big City }\end{array}$ & $\begin{array}{l}=1 \text { if borrower is located in a city with more than one million } \\
\text { inhabitants, }=0 \text { otherwise }\end{array}$ & $0 / 1$ & 559,945 & 30,811 & 0.651 & $0.835 * * *$ & 0.477 & 0.371 & 1 & 1 & 0 & 0 & 1 & 1 \\
\hline Share Religious Political Parties & $\begin{array}{l}\text { percentage of total votes obtained for National Assembly seats } \\
\text { by the coalition of six religious-political parties in General } \\
\text { Elections- } 2002 \text { in the district of the borrower }\end{array}$ & $\%$ & 560,454 & 31,357 & 13.911 & $17.378 * * *$ & 12.031 & 12.700 & 10.235 & 10.235 & 0 & 0 & 74.107 & 74.107 \\
\hline Share Private Post-Natal Care & $\begin{array}{l}\text { percentage of women who used private (and not public) } \\
\text { hospitals or clinics for post-natal care in the district of the } \\
\text { borrower }\end{array}$ & $\%$ & 560,734 & 31,424 & 0.208 & $0.229 * * *$ & 0.118 & 0.118 & 0.183 & 0.183 & 0 & 0 & 0.392 & 0.392 \\
\hline
\end{tabular}




\section{Table 5: All Banks}

The table reports the maximum likelihood estimation results of logit and duration models. The dependent variable in Model I equals one if the loan defaults and equals zero otherwise. The dependent variable in Model II equals one if the loan defaults in a certain month, and equals zero otherwise. The dependent variable in all other models is the hazard rate. The estimations in Models I and II employ logit models. The estimations in Models III to VI employ parametric duration models with a Weibull distribution that includes a parameter of duration dependence. Model VII reports the results of a Cox-proportional hazard model and includes borrower fixed effects. The sample period runs from 2006:04 to 2008:12. For each variable in the specification the table reports the estimated coefficient, statistical significance level and standard error (below in parentheses). In all estimations involving parametric models, standard errors are clustered by borrower.

\begin{tabular}{|c|c|c|c|c|c|c|c|c|}
\hline $\begin{array}{r}\text { Models } \\
\text { Estimation } \\
\text { Dependent Variable }\end{array}$ & $\begin{array}{c}\text { I } \\
\text { Logit } \\
\text { Loan Default } \\
0 / 1\end{array}$ & $\begin{array}{c}\text { II } \\
\text { Dynamic Logit } \\
\text { Loan-Month } \\
\text { Default 0/1 }\end{array}$ & $\begin{array}{c}\text { III } \\
\text { Dynamic Logit } \\
\text { Loan-Month } \\
\text { Default } 0 / 1\end{array}$ & $\begin{array}{c}\text { IV } \\
\text { Weibull } \\
\text { Hazard Rate }\end{array}$ & $\begin{array}{c}\mathrm{V} \\
\text { Weibull } \\
\text { Hazard Rate }\end{array}$ & $\begin{array}{c}\text { VI } \\
\text { Weibull } \\
\text { Hazard Rate }\end{array}$ & $\begin{array}{c}\text { VII } \\
\text { Weibull } \\
\text { Hazard Rate }\end{array}$ & $\begin{array}{c}\text { VIII } \\
\text { Cox } \\
\text { Hazard Rate }\end{array}$ \\
\hline Islamic Loan & $\begin{array}{c}-0.500 * * * \\
(0.148)\end{array}$ & $\begin{array}{c}-0.612 * * * \\
(0.144)\end{array}$ & $\begin{array}{c}-0.455 * * * \\
(0.158)\end{array}$ & $\begin{array}{c}-0.581 * * * \\
(0.144)\end{array}$ & $\begin{array}{c}-0.725 * * * \\
(0.157)\end{array}$ & $\begin{array}{c}-0.402^{* *} \\
(0.158)\end{array}$ & & $\begin{array}{c}-0.508 * * * \\
(0.193)\end{array}$ \\
\hline $\begin{array}{l}\text {-- by Islamic branch or subsidiary of conventional bank } \\
\text {-- by Islamic Bank }\end{array}$ & & & & & & & $\begin{array}{c}-0.262 \\
(0.189) \\
-0.781^{* * * *} \\
(0.238)\end{array}$ & \\
\hline $\begin{array}{l}\text { Borrower Characteristics } \\
\ln \text { (Size) }\end{array}$ & & & $\begin{array}{c}0.0107 \\
(0.0275)\end{array}$ & & $\begin{array}{r}-0.00934 \\
(0.0223)\end{array}$ & $\begin{array}{c}0.0148 \\
(0.0247)\end{array}$ & $\begin{array}{c}0.0145 \\
(0.0247)\end{array}$ & \\
\hline Loan Characteristics & & & & & & & & \\
\hline Maturity & & & $\begin{array}{c}0.00776 * * * \\
(0.00228)\end{array}$ & & $\begin{array}{c}0.00504 * * \\
(0.00222)\end{array}$ & $\begin{array}{l}0.00462 * \\
(0.00238)\end{array}$ & $\begin{array}{c}0.00472 * * \\
(0.00238)\end{array}$ & $\begin{array}{c}0.00909 * * * \\
(0.00138)\end{array}$ \\
\hline Collateral & & & $\begin{array}{l}-0.183 \\
(0.127)\end{array}$ & & $\begin{array}{c}-0.233^{* *} * \\
(0.114)\end{array}$ & $\begin{array}{l}0.0462 \\
(0.136)\end{array}$ & $\begin{array}{l}0.0476 \\
(0.136)\end{array}$ & $\begin{array}{l}-0.109 \\
(0.105)\end{array}$ \\
\hline Cash & & & $\begin{array}{c}2.217^{* * * *} \\
(0.111)\end{array}$ & & $\begin{array}{c}2.302 * * * \\
(0.109)\end{array}$ & $\begin{array}{c}2.185^{* * *} \\
(0.111)\end{array}$ & $\begin{array}{c}2.181 * * * \\
(0.112)\end{array}$ & $\begin{array}{c}1.509^{* * * *} \\
(0.109)\end{array}$ \\
\hline Export & & & $\begin{array}{l}0.0371 \\
(0.213)\end{array}$ & & $\begin{array}{l}-0.0152 \\
(0.211)\end{array}$ & $\begin{array}{c}0.00793 \\
(0.204)\end{array}$ & $\begin{array}{l}0.00947 \\
(0.204)\end{array}$ & $\begin{array}{c}-0.199 * * * \\
(0.0654)\end{array}$ \\
\hline Agricultural & & & $\begin{array}{l}-0.244 \\
(0.247)\end{array}$ & & $\begin{array}{c}-0.701 * * \\
(0.318)\end{array}$ & $\begin{array}{l}-0.302 \\
(0.251)\end{array}$ & $\begin{array}{l}-0.301 \\
(0.251)\end{array}$ & $\begin{array}{c}0.245 \\
(0.381)\end{array}$ \\
\hline Bank Characteristics & & & & & & & & \\
\hline Government & & & $\begin{array}{c}0.259 * * \\
(0.129)\end{array}$ & & & $\begin{array}{l}0.216^{*} \\
(0.123)\end{array}$ & $\begin{array}{l}0.213^{*} \\
(0.123)\end{array}$ & $\begin{array}{c}0.503 * * * \\
(0.121)\end{array}$ \\
\hline Specialized & & & $\begin{array}{l}-0.110 \\
(0.299)\end{array}$ & & & $\begin{array}{l}-0.113 \\
(0.305)\end{array}$ & $\begin{array}{l}-0.114 \\
(0.305)\end{array}$ & $\begin{array}{c}0.191 \\
(1.322)\end{array}$ \\
\hline Foreign & & & $\begin{array}{c}-0.768^{* *} \\
(0.339)\end{array}$ & & & $\begin{array}{c}-0.828^{* * *} \\
(0.339)\end{array}$ & $\begin{array}{c}-0.745^{* *} \\
(0.335)\end{array}$ & $\begin{array}{l}-0.552 \\
(0.374)\end{array}$ \\
\hline Large & & & $\begin{array}{c}0.763 * * * \\
(0.164)\end{array}$ & & & $\begin{array}{c}0.719 * * * \\
(0.154)\end{array}$ & $\begin{array}{c}0.718 * * * \\
(0.153)\end{array}$ & $\begin{array}{c}0.575^{* * * *} \\
(0.0984)\end{array}$ \\
\hline Intercept & $\begin{array}{c}-3.128 * * * \\
(0.0620) \\
\end{array}$ & $\begin{array}{c}-4.752^{* * * *} \\
(0.0608)\end{array}$ & $\begin{array}{c}-7.425^{* * *} * \\
(0.647)\end{array}$ & $\begin{array}{c}-4.759 * * * \\
(0.0995)\end{array}$ & $\begin{array}{c}-6.689 * * * \\
(0.476)\end{array}$ & $\begin{array}{c}-8.752 * * * \\
(1.169)\end{array}$ & $\begin{array}{c}-8.745 * * * \\
(1.168)\end{array}$ & \\
\hline Borrower Region dummies (7) & No & No & Yes & No & Yes & Yes & Yes & No \\
\hline Borrower Industry Dummies (67) & No & No & Yes & No & Yes & Yes & Yes & No \\
\hline Year*Month Fixed Effects & No & No & No & No & No & Yes & Yes & Yes \\
\hline Borrower Fixed Effects & No & No & No & No & No & No & No & Yes \\
\hline $\begin{array}{l}\text { Log Pseudolikelihood } \\
\text { a (Duration Dependence) }\end{array}$ & $\begin{array}{c}-20,995 \\
-\end{array}$ & $\begin{array}{c}-29,115 \\
-\end{array}$ & $\begin{array}{c}-26,525 \\
-\end{array}$ & $\begin{array}{c}-25,121 \\
0.978\end{array}$ & $\begin{array}{c}-23,013 \\
0.983\end{array}$ & $\begin{array}{c}-22,157 \\
0.962\end{array}$ & $\begin{array}{c}-22,154 \\
0.962\end{array}$ & $\begin{array}{c}-9,510 \\
-\end{array}$ \\
\hline $\mathrm{Chi}^{2}(\mathrm{k})$ [LR in VI, VII, IX \& XIII, Wald in others] & 11 & 18 & 1055 & 16 & 4,009 & 4,479 & 4,437 & 1,631 \\
\hline $\begin{array}{l}\text { Number of regressors minus one }(\mathrm{k}) \\
\text { Number of Loan-Months }\end{array}$ & $\frac{1}{-}$ & $\frac{1}{603.677}$ & $\frac{81}{581,620}$ & $\frac{1}{603,677}$ & $\begin{array}{c}81 \\
582,759\end{array}$ & $\frac{117}{582,759}$ & $\begin{array}{c}118 \\
582,759\end{array}$ & $\begin{array}{c}42 \\
603,677\end{array}$ \\
\hline Number of Loans & 122,331 & 152,730 & 146,849 & 152,730 & 149,302 & 149,302 & 149,302 & 152,730 \\
\hline Number of Borrowers & 19,063 & 22,723 & 21,848 & 22,723 & 21,866 & 21,866 & 21,866 & 22,723 \\
\hline
\end{tabular}




\section{Table 6: All Banks: Robustness}

The table reports the maximum likelihood estimation results of duration models. Models I to VIII report the results of a Cox-proportional hazard model and include borrower fixed effects. The estimation in Model IX employs a parametric duration model with a Weibull distribution that includes a parameter of duration dependence. The sample used in Model I contains only cash loans. The sample used in Models VII and VIII contains Murabaha and conventional loans given as working capital and term finance (excluding all other credit facilities, i.e., mortgage finance, leases, export finance, agricultural finance and off-balance financing). In Model VIII the sample is further restricted to loan that are collateralized and with a maturity short significance level and standard error (below in parentheses). In all estimations involving parametric models, standard errors are clustered by borrower.

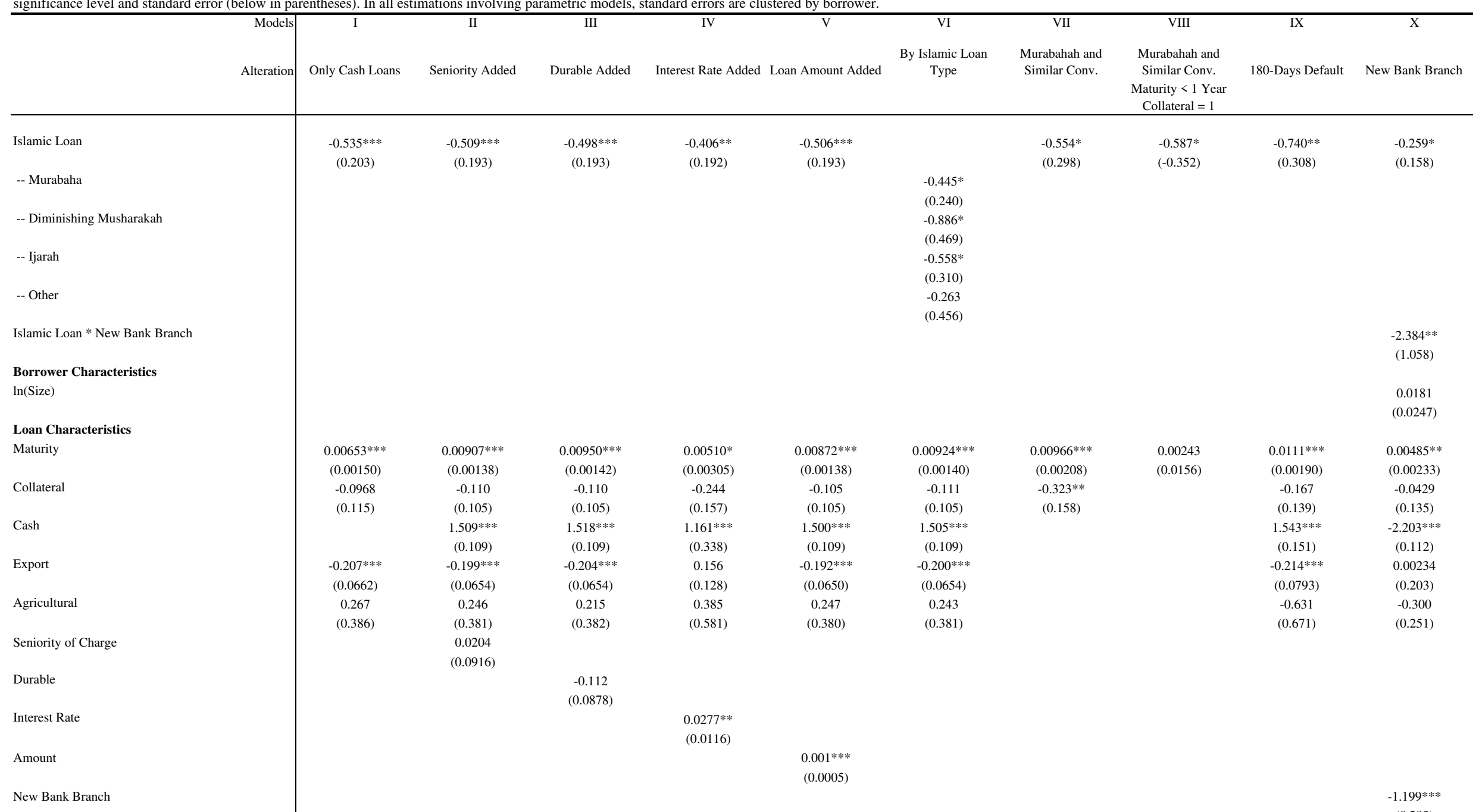




\begin{tabular}{|c|c|c|c|c|c|c|c|c|c|c|}
\hline \multicolumn{11}{|l|}{ Bank Characteristics } \\
\hline \multirow{2}{*}{$\begin{array}{l}\text { Bank Characteristics } \\
\text { Government }\end{array}$} & $0.533^{* * *}$ & $0.503^{* * *}$ & $0.498^{* * * *}$ & 0.383 & $0.442 * * *$ & $0.504^{* * *}$ & $0.561^{* * * *}$ & $1.414^{* * * *}$ & 0.202 & 0.199 \\
\hline & $(0.125)$ & $(0.121)$ & $(0.121)$ & $(0.279)$ & $(0.123)$ & $(0.121)$ & $(0.186)$ & $(0.306)$ & $(0.162)$ & $(0.123)$ \\
\hline \multirow{2}{*}{ Specialized } & 0.0772 & 0.187 & 0.239 & & 0.145 & 0.191 & -0.419 & & -36.03 & -0.138 \\
\hline & $(1.440)$ & $(1.321)$ & $(1.343)$ & & $(1.315)$ & $(1.322)$ & $(0.443)$ & & $(38.000)$ & $(0.305)$ \\
\hline \multirow[t]{2}{*}{ Foreign } & -0.529 & -0.551 & -0.558 & -0.201 & -0.554 & -0.507 & -0.596 & & 0.189 & $-0.908^{* * * * *}$ \\
\hline & $(0.401)$ & $(0.374)$ & $(0.374)$ & $(0.553)$ & $(0.372)$ & $(0.379)$ & $(0.674)$ & & $(0.481)$ & $(0.339)$ \\
\hline \multirow[t]{2}{*}{ Large } & $0.570^{* * *}$ & $0.574 * * * *$ & $0.568^{* * * * *}$ & $0.984 * *$ & $0.566 * * *$ & $0.578 * * *$ & $0.528^{* * * *}$ & 0.157 & $0.774 * * *$ & $0.694 * * *$ \\
\hline & $(0.102)$ & $(0.0983)$ & $(0.0984)$ & $(0.195)$ & $(0.0984)$ & $(0.0985)$ & $(0.138)$ & $(0.205)$ & $(0.130)$ & $(0.150)$ \\
\hline \multirow[t]{2}{*}{ Intercept } & & & & & & & & & & $-8.206 * * *$ \\
\hline & & & & & & & & & & $(1.153)$ \\
\hline Borrower Region dummies (7) & No & No & No & No & No & No & No & No & No & Yes \\
\hline Borrower Industry Dummies (67) & No & No & No & No & No & No & No & No & No & Yes \\
\hline Year*Month Fixed Effects & Yes & Yes & Yes & Yes & Yes & Yes & Yes & Yes & Yes & Yes \\
\hline Borrower Fixed Effects & Yes & Yes & Yes & Yes & Yes & Yes & Yes & Yes & Yes & No \\
\hline Log Pseudolikelihood & $-9,018$ & $-9,510$ & $-9,510$ & $-2,922$ & $-9,506$ & $-9,510$ & $-4,302$ & $-2,632$ & $-5,771$ & $-22,062$ \\
\hline a (Duration Dependence) & - & - & 然 & 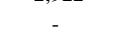 & - & - & 1,000 & - & - & 0.961 \\
\hline $\mathrm{Ch}^{2}(\mathrm{k})$ [LR in VI, VII, IX \& XIII, Wald in others] & 1,215 & 1,631 & 1,632 & 545 & 1,639 & 1,632 & 814 & 436.0 & 1,238 & 7,419 \\
\hline Number of regressors minus one $(\mathrm{k})$ & 41 & 43 & 43 & 41 & 43 & 45 & 38 & 35 & 42 & 119 \\
\hline Number of Loan-Months & 448,333 & 603,677 & 603,677 & 239,946 & 603,677 & 603,677 & 257,979 & 172,105 & 613,218 & 580,810 \\
\hline Number of Loans & 107,476 & 152,730 & 152,730 & 54,952 & 152,730 & 152,730 & 61,184 & 40,335 & 152,730 & 148,669 \\
\hline Number of Borrowers & 19,084 & 22,723 & 22,723 & 13,628 & 21,574 & 21,574 & 14,652 & 12,191 & 22,041 & 21,837 \\
\hline
\end{tabular}


Table 7: Mixed Banks

The table reports the maximum likelihood estimation results of duration models. Models I to III and V to VII employ parametric duration models with a Weibull distribution that includes a parameter of duration dependence. Model IV reports the results of a Cox-proportional hazard model and includes borrower fixed effects. The sample includes only loans given by banks that grant both conventional and $\underline{\text { Islamic }}$

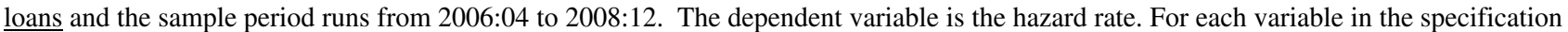
the table reports the estimated coefficient, statistical significance level and standard error (below in parentheses). In Models I to III and V to VII standard errors are clustered by borrower.

\begin{tabular}{|c|c|c|c|c|c|c|c|}
\hline & $\mathrm{I}$ & II & III & IV & $\mathrm{V}$ & VI & VII \\
\hline Islamic Loan & $\begin{array}{c}-1.601 * * * \\
(0.358)\end{array}$ & $\begin{array}{c}-1.869 * * * \\
(0.384)\end{array}$ & $\begin{array}{c}-1.654 * * * \\
(0.381)\end{array}$ & $\begin{array}{c}-2.015^{* *} \\
(0.865)\end{array}$ & $\begin{array}{l}-1.554 * \\
(0.928)\end{array}$ & & $\begin{array}{c}-1.374 * * * \\
(0.326)\end{array}$ \\
\hline $\begin{array}{l}\text {-- Borrowers with conventional and Islamic loans } \\
\text {-- Borrowers with only conventional loans }\end{array}$ & & & & & & $\begin{array}{c}0.196 \\
(0.580) \\
1.184 * * * \\
(0.426)\end{array}$ & \\
\hline $\begin{array}{l}\text {-- Borrowers that switch to Islamic loans (from conventional) } \\
\text {-- Borrowers that switch to conventional loans (from Islamic) }\end{array}$ & & & & & & & $\begin{array}{c}-0.877 * \\
(0.464) \\
-0.350 \\
(0.956)\end{array}$ \\
\hline $\begin{array}{l}\text { Borrower Characteristics } \\
\ln (\text { Size })\end{array}$ & & $\begin{array}{c}0.0147 \\
(0.0288)\end{array}$ & $\begin{array}{c}0.0345 \\
(0.0291)\end{array}$ & & & $\begin{array}{c}0.0431 \\
(0.0302)\end{array}$ & $\begin{array}{c}0.0429 \\
(0.0304)\end{array}$ \\
\hline \multicolumn{8}{|l|}{ Loan Characteristics } \\
\hline Maturity & & $\begin{array}{l}-0.00446 \\
(0.00390)\end{array}$ & $\begin{array}{l}-0.00799 * \\
(0.00429)\end{array}$ & $\begin{array}{l}0.00500 * \\
(0.00256)\end{array}$ & $\begin{array}{l}0.0071 * * * \\
(0.00276)\end{array}$ & $\begin{array}{l}-0.00807 * \\
(0.00429)\end{array}$ & $\begin{array}{l}-0.00804 * \\
(0.00429)\end{array}$ \\
\hline Collateral & & $\begin{array}{c}-0.479 * * * \\
(0.137)\end{array}$ & $\begin{array}{c}-0.559 * * * \\
(0.136)\end{array}$ & $\begin{array}{l}-0.204 * \\
(0.123)\end{array}$ & $\begin{array}{l}-0.238 * \\
(0.127)\end{array}$ & $\begin{array}{c}-0.551 * * * \\
(0.137)\end{array}$ & $\begin{array}{c}-0.552 * * * \\
(0.137)\end{array}$ \\
\hline Cash & & $\begin{array}{c}2.485 * * * \\
(0.148)\end{array}$ & $\begin{array}{c}2.357 * * * \\
(0.160)\end{array}$ & $\begin{array}{c}1.800 * * * \\
(0.169)\end{array}$ & $\begin{array}{c}1.786^{* * * *} \\
(0.178)\end{array}$ & $\begin{array}{l}2.350 * * * \\
(0.159)\end{array}$ & $\begin{array}{c}2.358 * * * \\
(0.159)\end{array}$ \\
\hline Export & & $\begin{array}{l}-0.0254 \\
(0.255)\end{array}$ & $\begin{array}{l}-0.0608 \\
(0.238)\end{array}$ & $\begin{array}{c}-0.239 * * * \\
(0.0757)\end{array}$ & $\begin{array}{l}-0.173 * * \\
(0.0790)\end{array}$ & $\begin{array}{l}-0.0558 \\
(0.236)\end{array}$ & $\begin{array}{l}-0.0611 \\
(0.237)\end{array}$ \\
\hline Agricultural & & $\begin{array}{c}0.238 \\
(0.193)\end{array}$ & $\begin{array}{l}0.0639 \\
(0.199)\end{array}$ & $\begin{array}{c}0.700 \\
(0.443)\end{array}$ & $\begin{array}{c}0.523 \\
(0.444)\end{array}$ & $\begin{array}{l}0.0591 \\
(0.199)\end{array}$ & $\begin{array}{l}0.0642 \\
(0.199)\end{array}$ \\
\hline Intercept & $\begin{array}{c}-4.734 * * * \\
(0.130)\end{array}$ & $\begin{array}{c}-6.657 * * * \\
(0.614)\end{array}$ & $\begin{array}{c}-6.907 * * * \\
(1.224)\end{array}$ & & & $\begin{array}{c}-8.162 * * * \\
(1.286)\end{array}$ & $\begin{array}{c}-7.004 * * * \\
(1.232)\end{array}$ \\
\hline Borrower Region dummies (7) & No & Yes & Yes & No & No & Yes & Yes \\
\hline Borrower Industry Dummies (67) & No & Yes & Yes & No & No & Yes & Yes \\
\hline Year*Month Fixed Effects & No & No & Yes & Yes & Yes & Yes & Yes \\
\hline Borrower Fixed Effects & No & No & No & Yes & No & No & No \\
\hline Bank Fixed Effects & No & No & Yes & Yes & No & Yes & Yes \\
\hline Borrower*Bank Fixed Effects & No & No & No & No & Yes & No & No \\
\hline $\begin{array}{l}\text { Log Pseudolikelihood } \\
\text { a (Duration Dependence) }\end{array}$ & $\begin{array}{c}-17,336 \\
1.009\end{array}$ & $\begin{array}{c}-15,824 \\
1.026\end{array}$ & $\begin{array}{l}-14,695 \\
\text { by bank }\end{array}$ & $\begin{array}{c}-6,863 \\
-\end{array}$ & $\begin{array}{c}-7031 \\
-\end{array}$ & $\begin{array}{l}-14,679 \\
\text { by bank }\end{array}$ & $\begin{array}{l}-14,674 \\
\text { by bank }\end{array}$ \\
\hline $\begin{array}{l}\mathrm{Chi}^{2}(\mathrm{k}) \text { [LR in VI-X, Wald in other] } \\
\text { Number of regressors minus one }(\mathrm{k})\end{array}$ & $\begin{array}{c}20 \\
1\end{array}$ & $\begin{array}{c}6,334 \\
81\end{array}$ & $\begin{array}{c}7,390 \\
123\end{array}$ & $\begin{array}{c}1,280 \\
46\end{array}$ & $\begin{array}{c}1019 \\
36\end{array}$ & $\begin{array}{c}7,768 \\
124\end{array}$ & $\begin{array}{c}7,819 \\
125 \\
\end{array}$ \\
\hline Number of Loan-Months & 378,649 & 372,415 & 372,415 & 378,649 & 378,649 & 372,415 & 372,415 \\
\hline Number of Loans & 109,157 & 107,944 & 107,944 & 109,157 & 109,157 & 107,944 & 107,944 \\
\hline Number of Borrowers & 15,653 & 15,355 & 15,355 & 15,653 & 15,653 & 15,355 & 15,355 \\
\hline
\end{tabular}

***, **, * indicate significance at $1 \%, 5 \%$ and $10 \%$ level, two-tailed. 


\section{Table 8: Religion as a Motivator to Perform on Loans}

The table reports the maximum likelihood estimation results of duration models. All estimations except in Model I employ parametric duration models with a Weibull distribution that includes a parameter of duration dependence. Model I reports the results of a Coxproportional hazard model and includes quarter dummies and borrower fixed effects. Estimations in Models II to V include only those loans that are granted in the four provinces and the federal capital (i.e., regions where Pakistani political parties can operate and key statistics are recorded) and exclude loans in other regions administered by Pakistan. The sample period runs from 2006:04 to 2008:12 The dependent variable is the hazard rate. For each variable in the specification the table reports the estimated coefficient, statistical significance level and standard error (below in parentheses). In all estimations below involving parametric models, standard errors are clustered by borrower.

\begin{tabular}{|c|c|c|c|c|c|}
\hline Models & $\mathrm{I}$ & \multicolumn{2}{|c|}{$\begin{array}{cc}\text { II } & \text { III } \\
\text { Share }=\text { Religious Political } \\
\text { Parties }\end{array}$} & \multicolumn{2}{|c|}{$\begin{array}{cc}\text { IV } & \text { V } \\
\text { Share }=\text { Post-Natal Private } \\
\text { Care }\end{array}$} \\
\hline Islamic Loan & $\begin{array}{c}-0.569 * * * \\
(0.191)\end{array}$ & $\begin{array}{l}-0.463 \\
(0.450)\end{array}$ & $\begin{array}{l}-0.859 \\
(0.715)\end{array}$ & $\begin{array}{c}-2.133 * * \\
(0.925)\end{array}$ & $\begin{array}{l}-1.667 \\
(1.185)\end{array}$ \\
\hline Islamic Loan * Ramadan & $\begin{array}{l}-0.696 * \\
(0.363)\end{array}$ & & & & \\
\hline Islamic Loan * Share & & $\begin{array}{c}0.0399 * * \\
(0.0169)\end{array}$ & $\begin{array}{c}0.0429 \\
(0.0269)\end{array}$ & $\begin{array}{c}13.13^{* *} \\
(6.533)\end{array}$ & $\begin{array}{c}9.050 \\
(9.136)\end{array}$ \\
\hline Islamic Loan * Big City & & $\begin{array}{l}0.0108 \\
(0.511)\end{array}$ & $\begin{array}{c}0.206 \\
(0.907)\end{array}$ & $\begin{array}{c}0.923 \\
(1.004)\end{array}$ & $\begin{array}{l}-0.331 \\
(1.360)\end{array}$ \\
\hline Islamic Loan * Share * Big City & & $\begin{array}{c}-0.0474 * * \\
(0.0202)\end{array}$ & $\begin{array}{c}-0.170^{* * *} \\
(0.0567)\end{array}$ & $\begin{array}{r}-10.830 \\
(6.666)\end{array}$ & $\begin{array}{l}-10.300 \\
(9.384)\end{array}$ \\
\hline \multicolumn{6}{|l|}{ Added Variables } \\
\hline Ramadan & $\begin{array}{l}-0.0481 \\
(0.0600)\end{array}$ & & & & \\
\hline Share & & $\begin{array}{c}0.00588 \\
(0.00462)\end{array}$ & $\begin{array}{c}0.00687 \\
(0.00525)\end{array}$ & $\begin{array}{c}0.324 \\
(0.837)\end{array}$ & $\begin{array}{l}-0.767 \\
(0.870)\end{array}$ \\
\hline Share * Big City & & $\begin{array}{l}0.000510 \\
(0.00676)\end{array}$ & $\begin{array}{c}0.00193 \\
(0.00756)\end{array}$ & $\begin{array}{l}-0.268 \\
(1.021)\end{array}$ & $\begin{array}{c}1.350 \\
(1.100)\end{array}$ \\
\hline \multicolumn{6}{|l|}{ Loan Characteristics } \\
\hline Maturity & $\begin{array}{c}0.0125^{* * *} * \\
(0.00133)\end{array}$ & $\begin{array}{l}0.00396^{*} \\
(0.00238)\end{array}$ & $\begin{array}{c}-0.00912 * * \\
(0.00418)\end{array}$ & $\begin{array}{l}0.00397^{*} \\
(0.00239)\end{array}$ & $\begin{array}{c}-0.00828^{* *} \\
(0.00417)\end{array}$ \\
\hline Collateral & $\begin{array}{c}0.331^{* * * *} \\
(0.0990)\end{array}$ & $\begin{array}{l}-0.022 \\
(0.134)\end{array}$ & $\begin{array}{c}-0.593 * * * \\
(0.134)\end{array}$ & $\begin{array}{l}-0.0253 \\
(0.133)\end{array}$ & $\begin{array}{c}0.577 * * * \\
(0.133)\end{array}$ \\
\hline Cash & $\begin{array}{c}-1.617 * * * \\
(0.107)\end{array}$ & $\begin{array}{c}2.256^{* * *} \\
(0.113)\end{array}$ & $\begin{array}{c}2.482 * * * \\
(0.163)\end{array}$ & $\begin{array}{c}2.240 \text { *** } \\
(0.113)\end{array}$ & $\begin{array}{c}2.454 * * * \\
(0.162)\end{array}$ \\
\hline Export & $\begin{array}{c}-0.192 * * * \\
(0.0620)\end{array}$ & $\begin{array}{l}-0.0536 \\
(0.204)\end{array}$ & $\begin{array}{l}-0.127 \\
(0.239)\end{array}$ & $\begin{array}{l}-0.0558 \\
(0.205)\end{array}$ & $\begin{array}{c}0.113 \\
(0.237)\end{array}$ \\
\hline Agricultural & $\begin{array}{c}0.217 \\
(0.368)\end{array}$ & $\begin{array}{l}-0.173 \\
(0.262)\end{array}$ & $\begin{array}{c}0.247 \\
(0.202)\end{array}$ & $\begin{array}{l}-0.177 \\
(0.265)\end{array}$ & $\begin{array}{c}0.218 \\
(0.202)\end{array}$ \\
\hline \multicolumn{6}{|l|}{ Borrower Characteristics } \\
\hline $\ln ($ Size $)$ & & $\begin{array}{c}0.0267 \\
(0.0465)\end{array}$ & $\begin{array}{c}0.0462 \\
(0.0626)\end{array}$ & $\begin{array}{c}0.0285 \\
(0.0469)\end{array}$ & $\begin{array}{c}0.0455 \\
(0.0636)\end{array}$ \\
\hline Big City & & $\begin{array}{c}0.395 * * * \\
(0.126)\end{array}$ & $\begin{array}{c}0.486^{* * *} * \\
(0.143)\end{array}$ & $\begin{array}{c}0.470 * * \\
(0.183)\end{array}$ & $\begin{array}{l}0.367 * \\
(0.198)\end{array}$ \\
\hline \multicolumn{6}{|l|}{ Bank Characteristics } \\
\hline Government & $\begin{array}{c}0.353^{* * *} \\
(0.115)\end{array}$ & $\begin{array}{l}0.239^{*} \\
(0.124)\end{array}$ & & $\begin{array}{l}0.229 * \\
(0.128)\end{array}$ & \\
\hline Specialized & $\begin{array}{l}-0.505 \\
(1.161)\end{array}$ & $\begin{array}{l}-0.0259 \\
(0.318)\end{array}$ & & $\begin{array}{l}-0.0512 \\
(0.314)\end{array}$ & \\
\hline Foreign & $\begin{array}{l}-0.515 \\
(0.360)\end{array}$ & $\begin{array}{c}-0.855^{* *} \\
(0.337)\end{array}$ & & $\begin{array}{c}-0.847 * * \\
(0.337)\end{array}$ & \\
\hline Large & $\begin{array}{l}0.659 * * * \\
(0.0967)\end{array}$ & $\begin{array}{c}0.823 * * * \\
(0.158)\end{array}$ & & $\begin{array}{c}0.803 * * * \\
(0.152)\end{array}$ & \\
\hline Intercept & & $\begin{array}{c}-7.145^{* * *} * \\
(1.308)\end{array}$ & $\begin{array}{c}-5.799^{* * *} \\
(1.535)\end{array}$ & $\begin{array}{c}-7.141^{* * *} \\
(1.308)\end{array}$ & $\begin{array}{c}-6.010^{* * *} \\
(1.561)\end{array}$ \\
\hline Region dummies (7) & No & No & No & No & No \\
\hline Industry Dummies (67) & No & Yes & Yes & Yes & Yes \\
\hline Year*Month Fixed Effects & $\mathrm{d}($ Quarter) & Yes & Yes & Yes & Yes \\
\hline Borrower Fixed Effects & Yes & No & No & No & No \\
\hline Bank Fixed Effects & No & No & Yes & No & Yes \\
\hline $\begin{array}{l}\text { Log Pseudolikelihood } \\
\alpha \text { (Duration Dependence) }\end{array}$ & $\begin{array}{c}-10,013 \\
-\end{array}$ & $\begin{array}{c}-21,928 \\
0.971\end{array}$ & $\begin{array}{c}-14,477 \\
1.021\end{array}$ & $\begin{array}{c}-21932 \\
0.970\end{array}$ & $\begin{array}{c}-14,554 \\
1.045\end{array}$ \\
\hline $\begin{array}{l}\mathrm{Chi}^{2}(\mathrm{k}) \text { [LR in VI, VII, IX \& XIII, Wald in others] } \\
\text { Number of regressors minus one }(\mathrm{k})\end{array}$ & $\begin{array}{c}625.8 \\
15\end{array}$ & $\begin{array}{l}4,179 * * * \\
116\end{array}$ & $\begin{array}{c}6,268^{* * *} \\
122\end{array}$ & $\begin{array}{l}4,166.30^{* * *} \\
116\end{array}$ & $\begin{array}{l}6,529.89^{* * *} \\
122\end{array}$ \\
\hline Number of Loan-Months & 603,677 & 578,809 & 369,816 & 579,144 & 370,063 \\
\hline Number of Loans & 152,730 & 148,316 & 107,215 & 148,397 & 107,282 \\
\hline Number of Borrowers & 22,723 & 21,574 & 15,144 & 21,586 & 15,153 \\
\hline
\end{tabular}


APPENDIX -- NOT FOR PUBLICATION 


\section{Appendix A: Types of Islamic Products}

This Appendix aims to provide a brief summary of the main issues in Islamic finance and the dominant types of Islamic products that are employed to finance small businesses. For more detail see Kettell (2010) for example.

Under Islamic economic philosophy, granting a loan is essentially a charitable activity and hence should occur without any compensation. The borrower may (and is encouraged to) voluntarily pay back more than the principal amount to show her/his gratitude towards lender, however, it is prohibited to make an agreement regarding any such additional payment.

If someone wants to earn profits from transferring money, then one must make an investment and share both in the risk and the return of the venture. The ideal modes of Islamic finance are thus Musharakah (partnership, where all partners invest both money and some or contribute their expertise) and Mudarabah (partnership with some partners investing only money and others only their skills/labor). Islamic banks, however, have devised a variety of other products that mimic the conventional banking products. Many of these products are based on sale contracts rather than loan contracts while others are based on rental contracts. Salient features of most widely used Islamic financial products are given below.

The first column lists the name of the Islamic banking product. The second column mentions the conventional (banking) product(s) that are similar to that particular Islamic product. The third column describes the way the product operates, the fourth column defines the default event and the last column describes the penalties in case of default.

\begin{tabular}{|c|c|c|c|c|}
\hline Islamic Product & $\begin{array}{l}\text { Conventional } \\
\text { Equivalent }\end{array}$ & Operation & Default & Penalties in the Event of Default \\
\hline
\end{tabular}




\begin{tabular}{|c|c|c|c|c|}
\hline & & $\begin{array}{l}\text { The customer pays the price in installments } \\
\text { over a period of time or in lump sum at an agreed } \\
\text { on date. } \\
\text { Notes: } \\
\text { Bank can appoint the customer as an agent to } \\
\text { purchase the underlying asset on its behalf, but } \\
\text { bank must retain the risk and return as the owner of } \\
\text { the asset. } \\
\text { Bank must own the asset before it could sell it. } \\
\text { Murabahah cannot be used to finance } \\
\text { commodities/assets already owned by the } \\
\text { customer. } \\
\text { Unlike a normal sale, the customer knows the cost } \\
\text { and profit of the bank. }\end{array}$ & & $\begin{array}{l}\text { 3. Bank can approach a court to } \\
\text { seek redressal, court may award } \\
\text { solatium to the bank to cover the } \\
\text { 'real losses' suffered like the cost of } \\
\text { litigation. Real losses do not include } \\
\text { time value of money. }\end{array}$ \\
\hline $\begin{array}{l}\text { Diminishing } \\
\text { Musharakah }\end{array}$ & $\begin{array}{l}\text { Hire-purchase, } \\
\text { mortgage } \\
\text { financing }\end{array}$ & $\begin{array}{l}\text { 1. Customer approaches the bank with a } \\
\text { request to finance a fixed asset (say building). } \\
\text { 2. Bank agrees to a joint ownership with the } \\
\text { customer and agrees to finance say } 80 \% \text { of the } \\
\text { value of the building, worth } \$ 10 \mathrm{M} \text {. } \\
\text { 3. Bank pays } \$ 8 \mathrm{M} \text { to seller, customer pays } \\
\$ 2 \mathrm{M} \text { to seller. } \\
4 . \quad \text { The bank divides its ownership in say } 20 \\
\text { parts and the customer undertakes to purchase } \\
\text { those parts at agreed dates. } \\
5 \text { The customer uses the building and pays } \\
\text { rent to the bank for its } 80 \% \text { ownership in the }\end{array}$ & $\begin{array}{l}\text { Default occurs when the } \\
\text { customer misses a } \\
\text { payment. } \\
\text { The facility is classified } \\
\text { as non-performing when } \\
\text { a payment is overdue by } \\
90 \text { days or more. } \\
\text { Breach of promise also } \\
\text { occurs if the customer } \\
\text { does not keep her/ his } \\
\text { promise to purchase } \\
\text { bank's share in asset. }\end{array}$ & $\begin{array}{l}\text { 1. Bank cannot change the rent } \\
\text { or sale price of its share in asset once } \\
\text { it is fixed. } \\
\text { 2. To contain moral hazard on } \\
\text { part of customer regarding delayed } \\
\text { payment or non-payment of any } \\
\text { amount when it is due, the customer } \\
\text { undertakes that s/he will give } \mathrm{x} \% \text { per } \\
\text { annum of the overdue amount for the } \\
\text { period of default to a charity fund } \\
\text { managed by the bank. } \\
\text { 3. Bank can approach a court to } \\
\text { seek redressal, court may award } \\
\text { solatium to the bank to cover 'real }\end{array}$ \\
\hline
\end{tabular}




\begin{tabular}{|c|c|c|c|c|}
\hline & & $\begin{array}{l}\text { building. } \\
\text { 6. At agreed dates, the customer purchases } \\
\text { the bank's shares in the building, the ownership in } \\
\text { the building gradually transfers to the customers. } \\
\text { 7. The bank's share in rent of the building } \\
\text { decreases proportionally. } \\
\text { Notes: } \\
\text { The contract of joint ownership and the promise to } \\
\text { purchase the shares in asset from bank cannot be } \\
\text { made conditional on each other. } \\
\text { The promise to purchase bank's share is essentially } \\
\text { a unilateral promise by the customer. }\end{array}$ & & $\begin{array}{l}\text { losses' suffered by it like the cost of } \\
\text { litigation. Real losses do not include } \\
\text { time value of money. }\end{array}$ \\
\hline Ijarah & Operating lease & $\begin{array}{l}\text { 1. It involves the transfer of usufruct but not } \\
\text { ownership of the asset at an agreed rent. } \\
\text { 2. Customer (lessee) approaches the bank } \\
\text { (lessor) for lease of a specific asset and makes a } \\
\text { promise to lease that asset. } \\
\text { 3. The bank purchases the asset, or it may } \\
\text { appoint customer to purchase the asset as its agent. } \\
4 \quad \quad \text { After acquisition, the bank rents the asset } \\
\text { to the customer for a specific rent; rent may vary } \\
\text { for different periods. } \\
\text { 5. The customer pays the rent on agreed } \\
\text { dates. } \\
\text { Notes: } \\
\text { Anything, which cannot be used without }\end{array}$ & $\begin{array}{l}\text { Default occurs when the } \\
\text { lessee misses a payment. } \\
\text { The facility is classified } \\
\text { as non-performing when } \\
\text { a payment is overdue by } \\
90 \text { days or more. }\end{array}$ & $\begin{array}{l}\text { 1. Bank cannot change the rent } \\
\text { once it is fixed. } \\
\text { 2. To contain moral hazard on } \\
\text { part of customer regarding delayed } \\
\text { payment or non-payment of any } \\
\text { amount when it is due, the customer } \\
\text { undertakes that s/he will give } \mathrm{x} \% \text { per } \\
\text { annum of the overdue amount for the } \\
\text { period of default to a charity fund } \\
\text { managed by the bank. } \\
\text { 3. Bank can approach a court to } \\
\text { seek redressal, court may award } \\
\text { solatium to the bank to cover 'real } \\
\text { losses' suffered by it like the cost of } \\
\text { litigation. Real losses do not include } \\
\text { time value of money. }\end{array}$ \\
\hline
\end{tabular}




\begin{tabular}{|c|c|c|c|c|}
\hline & & $\begin{array}{l}\text { consuming, cannot be leased out, for example } \\
\text { money, wheat etc. } \\
\text { Bank retains the risks and rewards of the owner. } \\
\text { Customer is responsible for the costs and benefits } \\
\text { as the user of the asset } \\
\text { The lease agreement can be terminated with the } \\
\text { mutual consent of lessee and lessor or it can be } \\
\text { terminated by lessor if the lessee contravenes any } \\
\text { terms of lease. }\end{array}$ & & \\
\hline $\begin{array}{l}\text { Ijarah wa' } \\
\text { Iqtina }\end{array}$ & Financial lease & $\begin{array}{l}\text { 1. It involves transferring of usufruct of the } \\
\text { asset, and at the end of lease period ownership of } \\
\text { the asset also transfers to customer. } \\
\text { 2. Customer (lessee) approaches the bank } \\
\text { (lessor) for the lease of a specific asset and makes a } \\
\text { promise to lease that asset. } \\
\text { 3. The bank purchases the asset, or it may } \\
\text { appoint customer to purchase the asset as its agent. } \\
\text { 4. The bank makes a separate promise to give } \\
\text { the asset to the lessee at the end of lease period as a } \\
\text { gift or to sell the asset for a specific price. The } \\
\text { promise must be unilateral i.e. not binding on } \\
\text { lessee and it cannot be conditional on the lease } \\
\text { contract. } \\
\text { 5. After acquisition, bank rents the asset to } \\
\text { the customer for a specific rent; rent may vary for } \\
\text { different periods. } \\
\text { 6. The customer pays the rent on agreed }\end{array}$ & $\begin{array}{l}\text { Default occurs when the } \\
\text { lessee misses a payment. } \\
\text { The facility is classified } \\
\text { as non-performing when } \\
\text { a payment is overdue by } \\
90 \text { days or more. }\end{array}$ & $\begin{array}{l}\text { 1. Bank cannot change the rent } \\
\text { or sale price of the asset once it is } \\
\text { fixed. } \\
\text { 2. To contain moral hazard on } \\
\text { part of customer regarding delayed } \\
\text { payment or non-payment of any } \\
\text { amount when it is due, the customer } \\
\text { undertakes that s/he will give } \mathrm{x} \% \text { per } \\
\text { annum of the overdue amount for the } \\
\text { period of default to a charity fund } \\
\text { managed by the bank. } \\
\text { 3. Bank can approach a court to } \\
\text { seek redressal, court may award } \\
\text { solatium to the bank to cover 'real } \\
\text { losses' suffered by it like the cost of } \\
\text { litigation. Real losses do not include } \\
\text { time value of money. }\end{array}$ \\
\hline
\end{tabular}




\begin{tabular}{|c|c|c|c|c|}
\hline & & $\begin{array}{l}\text { dates. } \\
\text { 7. At the end of the Ijarah period, the bank } \\
\text { sells the asset to the customer or gives it away to } \\
\text { customer as gift. } \\
\text { Note: } \\
\text { The contract of Ijarah cannot be conditional on } \\
\text { signing the promise of sale or gift. The promise } \\
\text { must be made separately. }\end{array}$ & & \\
\hline
\end{tabular}




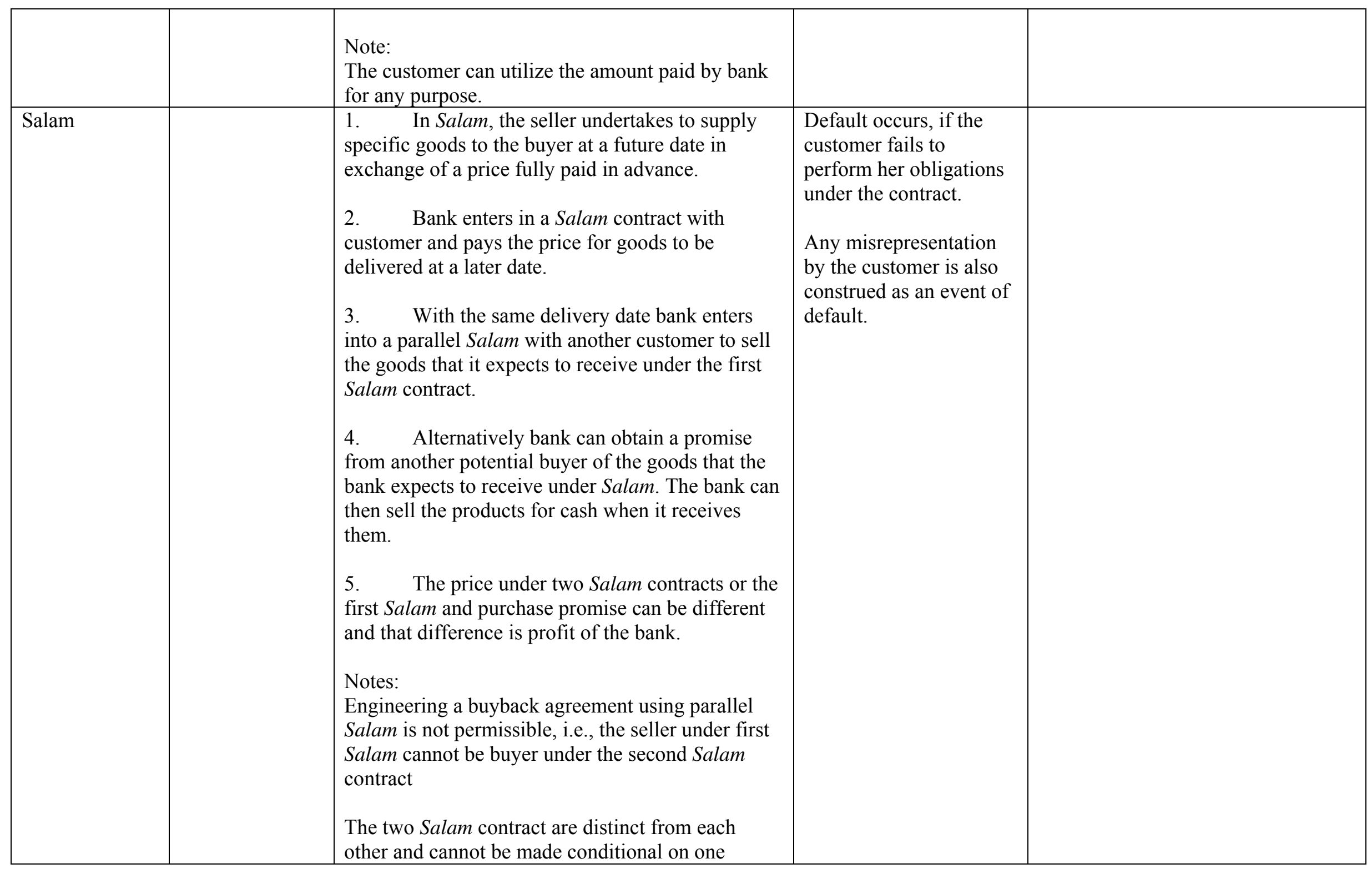




\begin{tabular}{|c|c|c|c|c|}
\hline & & $\begin{array}{l}\text { another. } \\
\text { Bank can ask for security or guarantee to ensure } \\
\text { performance on part of its customer }\end{array}$ & & \\
\hline Musharakah & Joint venture & $\begin{array}{l}\text { Musharakah is a relationship between two } \\
\text { parties or more, who contribute capital to a } \\
\text { business, and divide the net profit and loss. All } \\
\text { providers of capital are entitled to participate in } \\
\text { management, but not necessarily required to do so. } \\
\text { The profit is distributed among the partners in pre- } \\
\text { agreed ratios, while the loss is borne by each } \\
\text { partner strictly in proportion to respective capital } \\
\text { contributions. } \\
\text { 2. Bank and customer enter into a Musharaka } \\
\text { agreement by investing a certain sum of capital in } \\
\text { the business for a specified period of time. } \\
\text { 3. Bank and customer also define the share of } \\
\text { each party in expected profits. The customer also } \\
\text { gives an (annual) projection of profit. } \\
\text { 4. The customer periodically (monthly/ } \\
\text { quarterly) pays the profit to the bank based on the } \\
\text { profit projections and bank's share in profit. } \\
\text { 5. These profit payments are provisional and } \\
\text { are subject to upward or downward adjustments } \\
\text { based on the realized profits/losses. } \\
6 \text { At the end of Musharaka contract, } \\
\text { customer pays back the capital of the bank net of } \\
\text { profits/losses. } \\
\text { Notes: }\end{array}$ & $\begin{array}{l}\text { Default occurs if the } \\
\text { customer fails to make } \\
\text { profit or capital } \\
\text { payments when they are } \\
\text { due. } \\
\text { The facility is classified } \\
\text { as non-performing when } \\
\text { a payment is overdue by } \\
90 \text { days or more. }\end{array}$ & $\begin{array}{l}\text { 1. If the business suffers losses, } \\
\text { then bank assumes the losses in } \\
\text { proportion to its investment. } \\
\text { 2. To contain moral hazard on } \\
\text { part of customer regarding delayed } \\
\text { payment or non-payment of any } \\
\text { amount when it is due, the customer } \\
\text { undertakes that s/he will give } \mathrm{x} \% \text { per } \\
\text { annum of the overdue amount for the } \\
\text { period of default to a charity fund } \\
\text { managed by the bank. } \\
\text { 3. Bank can approach a court to } \\
\text { seek redressal, court may award } \\
\text { solatium to the bank to cover 'real } \\
\text { losses' suffered by it like the cost of } \\
\text { litigation. Real losses do not include } \\
\text { time value of money. }\end{array}$ \\
\hline
\end{tabular}




\begin{tabular}{|c|c|c|c|c|}
\hline & & $\begin{array}{l}\text { Return can be fixed as a percentage of profit but } \\
\text { not as a percentage of investment. } \\
\text { Share of an active partner in profit can be more } \\
\text { than her/his contribution to capital. A sleeping } \\
\text { partner cannot share in profit more than her/his } \\
\text { share is capital. } \\
\text { Loss is always shared proportional to the invested } \\
\text { capital. }\end{array}$ & & \\
\hline
\end{tabular}




\begin{tabular}{|c|c|c|c|c|}
\hline & & $\begin{array}{l}\text { net of any accrued profits or losses. } \\
\text { Notes: } \\
\text { Return can be fixed as a percentage of profit but } \\
\text { not as a percentage of investment. } \\
\text { Losses are always absorbed by the } \\
\text { financier(s)/bank. }\end{array}$ & & \\
\hline Qard-e-Hasna & $\begin{array}{l}\text { Benevolent } \\
\text { Loan }\end{array}$ & $\begin{array}{l}\text { 1. The borrower approaches the bank for } \\
\text { financing. } \\
\text { 2. The bank agrees to give loan to customer } \\
\text { for a certain period, to be paid back in installments } \\
\text { or in one go. } \\
\text { 3. Bank can charge service fee, and } \\
\text { documentation charges. } \\
\text { 4. Bank cannot claim any other interest or } \\
\text { profits for time value of money. }\end{array}$ & $\begin{array}{l}\text { Default occurs when the } \\
\text { customer fails to pay an } \\
\text { amount when it is due. } \\
\text { The facility is classified } \\
\text { as non-performing when } \\
\text { a payment is overdue by } \\
90 \text { days or more. }\end{array}$ & $\begin{array}{l}\text { 1. Bank cannot any additional } \\
\text { amount in the event of default by the } \\
\text { borrower. } \\
\text { 2. To contain moral hazard on } \\
\text { part of customer regarding delayed } \\
\text { payment or non-payment of any } \\
\text { amount when it is due, the customer } \\
\text { undertakes that s/he will give } \mathrm{x} \% \text { per } \\
\text { annum of the overdue amount for the } \\
\text { period of default to a charity fund } \\
\text { managed by the bank. } \\
\text { 3. Bank can approach a court to } \\
\text { seek redressal, court may award } \\
\text { solatium to the bank to cover 'real } \\
\text { losses' suffered by it like the cost of } \\
\text { litigation. Real losses do not include } \\
\text { time value of money. }\end{array}$ \\
\hline
\end{tabular}




\section{Appendix B: Banks}

The appendix reports the banks by type (and which therefore may appear in more than one category).

\section{Banks}

Islamic Banks

Albaraka Islamic Bank B.S.C. (E.C.)

Meezan Bank Ltd.

Dubai Islamic Bank Pakistan Ltd.

BankIslami Pakistan Limited

Emirates Global Islamic Bank

Dawood Islamic Bank Ltd.

Government Banks

The Bank of Khyber

The Bank of Punjab

First Women Bank Limited

National Bank of Pakistan

Specialized Banks

IDPB (industrial development)

Punjab Provincial Cooperative Bank Ltd.

SME Bank

ZTBL (agricultural development)

Foreign Banks

Albaraka Islamic Bank B.S.C. (E.C.)

Barclays Bank Plc

Citi Bank N.A.

Deutsche Bank A.G.

Hong Kong \& Shanghai Banking Corporation

Oman International Bank S.A.O.G.

The Bank of Tokyo-Mitsubishi Ltd.

Large Banks

Bank Alfalah Limited

Habib Bank Limited

MCB Bannk Limited

National Bank of Pakistan

United Bank Limited

Banks with Both Islamic and Conventional Loans

Askari Commercial Bank Limited

Bank Alfalah Limited

Bank Al-Habib Limited

Bank of Khyber

Habib Bank Limited

Habib-Metropolital Bank Limited

MCB Bannk Limited

National Bank of Pakistan

Royal Bank of Scotland (Formerly ABN Amro Bank NV)

Soneri Bank Limited

Standard Chartered Bank Limited

United Bank Limited

All Other Banks (Smaller Private Domestic Banks Offering only Conventional Loans)

Allied Bank Limited

Arif Habib Rupali Bank Limited

Atlas Bank Limited

Crescent Commercial Bank Limited

Faysal Bank Limited

JS Bank Limited

KASB Bank Limited

Mybank Limited

NIB Bank Ltd

Saudi Pak Commercial Bank Limited

Soneri Bank Limited 
Appendix C: Regions and Industries

The appendix reports the names of the regions and industries.

Regions

Province of Punjab

Province of Sindh

North-Western Frontier Province (renamed as Khyber Pakhtoonkhwa in 2010)

Province of Baluchistan

Federal Capital Area

(Pakistan Administered) Azad Kashmir

Federally Administered Tribal Area

Federally Administered Northern Area (Gilgit Baltistan as of 29 August 2009)

Industries (Sectors)

Agriculture, hunting and forestry - Others

Commerce and Trade- Retail trade

Commerce and Trade- Sale, maintenance and repair of motor vehicles and motor cycles

Commerce and Trade- Wholesales and commission trade

Construction- Buildings

Construction- Infrastructure

Education

Electricity, gas and water supply

Fishing, farming, aquaculture and related service activities

Foreign constituents

Health and social work

Hotels, restaurants and clubs

Insurance

Manufacturing- Basic metals

Manufacturing- Chemicals and chemical products

Manufacturing- Electrical machinery and apparatus

Manufacturing- Fabricated metal products

Manufacturing- Furniture and fixture

Manufacturing- Handicrafts

Manufacturing- Jewellery and related articles

Manufacturing- Machinery and equipments

Manufacturing- Medical, precision and optical instruments, watches and clocks

Manufacturing- Motor vehicles, trailers and semi - trailers

Manufacturing- Office, accounting and computing machinery

Manufacturing- Other sectors

Manufacturing- Other non - metallic mineral products

Manufacturing- Other transport equipment

Manufacturing- Petroleum products

Manufacturing- Radio, television and communication equipments and apparatus

Manufacturing- Rubber and plastic products

Manufacturing- Sport goods

Manufacturing- Food products

Manufacturing- Papers, paper boards and products

Manufacturing- Printing, publishing and allied industries

Manufacturing- Tanning and dressing of leather

Manufacturing- Textiles- Weaving

Manufacturing- Textiles- Spinning

Manufacturing- Textiles- Finishing

Manufacturing- Textiles- Made-up

Manufacturing- Textiles- Knitwear

Manufacturing- Textiles- Carpets and rugs

Manufacturing- Textiles- Wearing apparel, ready made garments and dressing

Manufacturing- Textiles- Other

Manufacturing- Tobacco

Manufacturing- Wood products

Mining and quarrying

Other community, social and personal service activities

Other service sectors

Real estate, renting and business activities

Ship breaking

Transport, storage and communication

Trust funds and non-profit organizations

Trading

Petroleum

Beverages

Cement

Telecommunication

Surgical and medical instruments

Footware

Sugar

Oil and gas expolaration

Power generation

Refinaries

Fertilizers

Agriculture- Rice

Agriculture- Raw cotton

Agriculture- Whea

Miscellaneous Industries 
Appendix D: Penalties at the Conventional and Islamic Branches of Various Mixed Banks

The table reports the penalties by loan type at the conventional and Islamic branches of various mixed banks as reported on their websites in March 2011. All amounts are in PKR

\begin{tabular}{|c|c|c|c|c|}
\hline$\overline{\text { Bank }}$ & Branch & Car Loan & Home Loan & Credit Card \\
\hline \multirow[t]{2}{*}{ Alhabib } & Conventional & $500 /$ installment \& check return charges of $500^{*}$ & $400 /$ installment \& check return charges of 500 & \\
\hline & Islamic & N/a & $\mathrm{N} / \mathrm{a}$ & \\
\hline \multirow[t]{2}{*}{ Askari } & Conventional & $3 \%$ of amount due $\&$ check return charges of $500^{*}$ & $750 /$ installment \& check return charges of 500 & \\
\hline & Islamic & No & No & \\
\hline \multirow[t]{2}{*}{ Bank Alfalah } & Conventional & Min. per installment: $100 /$ day or $1,000 /$ month & $\begin{array}{l}\text { Per installment (for loans up to } 1 \text { million): 500/month } \\
\text { [for average loan around } 8 \% \text { on unpaid amount] }\end{array}$ & \\
\hline & Islamic & No & Regular rent on unpaid amount & \\
\hline \multirow[t]{2}{*}{ Bank of Khyber } & Conventional & As per sanction letter \& check return charges of $500^{*}$ & as per sanction letter \& check return charges of $500^{*}$ & \\
\hline & Islamic & No & No & \\
\hline \multirow[t]{2}{*}{ Habib Bank } & Conventional & $600 /$ month & $600 /$ month & \\
\hline & Islamic & No & No & \\
\hline \multirow[t]{2}{*}{$\overline{\mathrm{UBL}}$} & Conventional & $1,000 /$ month unless contract stipulates differently & 1,000 unless contract stipulates differently & \\
\hline & Islamic & $\begin{array}{l}\text { Max. } 20 \% / y e a r \text { of the amount due [for a Toyota Corolla, } \\
5 \text { year financing, } 0 \% \text { equity around 550/month] }\end{array}$ & N/a & \\
\hline \multirow[t]{2}{*}{$\begin{array}{l}\text { Royal Bank of Scotland (merged } \\
\text { into Faysal Bank as of 01-Jan- } \\
\text { 2011; its schedule applies) }\end{array}$} & Conventional & $\begin{array}{l}\text { 600/installment, collection charges of } 465 / \text { visit \& check } \\
\text { return charges as per schedule ( } 0 \text { in the reference } \\
\text { schedule of charges) }\end{array}$ & $\begin{array}{l}\text { higher of } 1,000 \text { or } 10 \% \text { of amount due, collection } \\
\text { charges } 475 / \text { visit \& check return charges as per schedule } \\
\text { ( } 0 \text { in the reference schedule of charges) }\end{array}$ & \\
\hline & Islamic & Same as above & Same as above & \\
\hline Soneri & $\begin{array}{l}\text { Conventional } \\
\text { Islamic }\end{array}$ & $\begin{array}{l}500 / \text { month for all products } \\
\text { Per agreement }\end{array}$ & & \\
\hline Standard Chartered & $\begin{array}{l}\text { Conventional } \\
\text { Islamic }\end{array}$ & $\begin{array}{l}\text { Up to } 1,000 \\
\text { Up to } 1,000\end{array}$ & $\begin{array}{l}\text { Up to } 1,000 \\
\text { Up to } 1,000 \& 2 \% \text { pro month on amount due }\end{array}$ & $\begin{array}{l}\text { higher of up to } 1,500 \text { or } 10 \% \text { of amount due } \\
\text { No }\end{array}$ \\
\hline
\end{tabular}

Max.= Maximum. Min.= Minimum. No = not mentioned in the schedule of charges; The bank cannot charge anything unless a clause in the individual loan contract mentions a penalty. N/a= We could not track the

penalty schedule, or it is not available. $*=$ The bank receives undated checks from the borrower with the amount of an installment and when the customer misses an installment payment submits the check. 